\title{
AKUSTIČKE ZNAČAJKE VOKALNOGA ZAMORA
}

\author{
GORDANA KOVAČIĆ ${ }^{1}$ I EMICA FARAGO ${ }^{2}$ \\ ${ }^{1}$ Odjel Spikeri i voditelji, Hrvatska radiotelevizija, Zagreb, gordana.kovacic@hrt.hr \\ ${ }^{2}$ Odsjek za logopediju, Edukacijsko-rehabilitacijski fakultet, Sveučilišta u Zagrebu, Zagreb
}

Primljeno: 3.1 .2017 .

Izvorni znanstveni rad

Prihvaćeno: 15.3.2017.

UDK: 81'342

Sažetak: Vokalni se zamor temelji na samopercepciji povećanog laringalnog naprezanja i promjena kvalitete glasa. Može imati organsku i/ili funkcionalnu etiologiju. Ponajviše pogađa vokalne profesionalce među kojima su nastavnici najbrojniji. Unatoč brojnim istraživanjima, pitanje akustičkih značajki vokalnoga zamora još je otvoreno. Motiv je to i ovog istraživanja provedenog na uzorku nastavnica. Postavljena je hipoteza prema kojoj postoje značajne razlike u akustičkim varijablama glasa između nastavnica s vokalnim zamorom $(N=23)$ i nastavnica bez vokalnoga zamora $(N=27)$. Tekući govor i produžena fonacija vokala lal analizirani su u programu PRAAT računanjem dugotrajnog prosječnog spektra LTAS-a govora. Mjerilo se prosječni govorni $F_{0}$ i niz spektralnih veličina: jakost najjačeg spektralnog vrha L0, omjer a (omjer energije područja frekvencija 0-1 kHz i područja 1-5 kHz) te varijable $\Delta 1, \Delta 2, \Delta 3$ i $\Delta 4$ koje iskazuju omjer spektralnih energija područja viših frekvencija i to pojaseva 1-2 $\mathrm{kHz}$, 2-3 kHz, 3-4 kHz i 4-5 kHz i referentnog područja 0-1 kHz. Računalo se i prosječni $\mathrm{H}_{1} / \mathrm{H}_{2}$ iz harmoničkog spektra triju uzoraka produžene fonacije vokala /a/. Hipoteza je testirana multivarijatnom i univarijatnim analizama varijance te diskriminativnom analizom. Rezultati obrada pokazali su da ne postoje statistički značajne razlike u skupu akustičkih varijabli između skupina nastavnica. Postavljena je hipoteza odbačena. Međutim, kao pojedinačni se diskriminator izdvojio govorni $F_{0}$ čija je prosječna vrijednost u skupini nastavnica bez vokalnoga zamora $194 \mathrm{~Hz}$, a u skupini nastavnica s vokalnim zamorom ispodprosječnih $176 \mathrm{~Hz}$ što signalizira poremećaj. Nepostojanje akustičkih razlika između skupina nastavnica objašnjeno je nizom mogućih faktora, a najsnažnije činjenicom da je utvrđen podjednak broj vokalnih i tjelesnih subjektivnih smetnji čime se potvrđuje kompleksna fenomenologija sindroma vokalnog zamora, ali i sužuje snaga akustičke analize kao alata za njegovo otkrivanje.

Ključne riječi: vokalni zamor, akustička analiza, dugotrajni prosječni spektar LTAS, govorni $F_{0}$, nastavnici

\section{UVOD}

Vokalni je zamor jedna od ključnih riječi znanosti o glasu, osobito od 1990-ih. Unatoč velikom broju istraživanja, njegova fiziološka i biomehanička priroda i dalje intrigiraju znanstvene umove. Njemački su ga liječnici s kraja 19. stoljeća i početka 20-oga, primjerice Bernhard Fränkel i Theodor Simon Flatau, opisali kao slabost glasa koju su različito nazivali - mogiphonia, phonasthenia (prema Zehmisch i sur., 1979). Amerikanac Chevalier Jackson (1940) isticao je premorenost intrinzičnih laringalnih mišića (tiroaritenoidnih) uslijed koje dolazi do pojave niza subjektivnih simptoma na razini larinksa poput slabosti, stegnutosti i boli na što se ponajviše žale oni pojedinci koji glas koriste profesionalno. Spomenuti je liječnik izdvojio zloupotrebu glasa, odnosno izravnu i neizravnu laringalnu traumu kao glavne uzroke pojave vokalnoga zamora u što se i danas vjeruje, a naziva ih se $\mathrm{i}$ vokalnim predoziranjem. Pisao je i o predispoziciji za vokalni zamor koju ističu i današnji autori sintagmom slabašan larinks ("tender larynx") (Hunter i Titze, 2009). Uz spomenute laringalne simptome, vokalni se zamor manifestira i nizom drugih subjektivnih smetnji. To su suhoća grla i/ili ždrijela, potreba za iskašljavanjem, stezanje u grlu i prsima, neugodan osjećaj u vratu i ramenima, bolna fonacija, bolno gutanje, govorenje/pjevanje uz povećan napor, promjene visine glasa i glasnoće, manji tonski i dinamički raspon glasa, smanjena glasovna izražajnost, nestabilna kvaliteta glasa, opadanje snage glasa tijekom dana (Munier i Farell, 2016; Blaži i Heđever, 2010; Ilomäki i sur., 2009; Lehto i sur., 2006; Welham i Maclagan, 2004; Kovačić, 2003; Kostyk i Rochet, 1998; Eustace i sur., 1996; Johnson, 1994; Kitch i Oates, 1994). Iz nabrojenog se razabire da je među subjektivnim simptomima velik broj tjelesnih smetnji, a ne samo vokalnih. One mogu biti čujne u rasponu od jedva slušno opažljivih disfonija do vrlo jakih (pa i afonije). 
Ovo istraživanje želi ispitati učinkovitost sofisticirane tehnologije brze i neinvazivne akustičke analize $u$ detekciji vokalnoga zamora te koje su njegove akustičke značajke. Na to se pitanje već dulje vrijeme nastoji pronaći odgovor jer njegovo bi iznalaženje doprinijelo ranom otkrivanju sindroma vokalnoga zamora pa i njegovoj prevenciji. Najviše se po tom pitanju učinilo na području mjerenja učinaka akutnoga vokalnoga zamora u laboratorijskim uvjetima induciranog različitim vrstama fonacijskog opterećenja u raznovrsnim ergonomskim uvjetima, a manje u stvarnim situacijama. $\mathrm{U}$ oba slučaja rezultati nisu konzistentni što opravdava daljnja istraživanja u tom smjeru, no i iznova potvrđuje složenost ovog fenomena. Govoreći o nekonzistentnosti rezultata treba naglasiti da su autori koji su se uhvatili te problematike koristili različite metodologije. Tako su Lauri i sur. (1997) mjerili glasove 40 žena i 40 muškaraca koji su u različitim ergonomskim uvjetima pet puta po 45 minuta čitali naglas čime se simulirao radni dan nastavnika. Rezultati analize glotalnoga signala snimljenog prije i poslije eksperimenta, a ekstrahirani metodom inverznog filtriranja akustičkog signala, pokazali su promjene u smjeru vokalne hiperfunkcije u skupini žena. Laukkanen i sur. (2004a) su na uzorku 24 žene prosječne životne dobi 38 godina mjerili učinke vokalnog opterećenja izazvanog 45-minutnim čitanjem glasnoćom kojom se glasa u učionici srednje veličine. Utvrdili su značajne razlike između početnog i završnog mjerenja u samoprocjeni vokalnog zamora, poteškoćama u foniranju, iritaciji i boli u grlu te promuklosti, a akustičkom analizom uzoraka govora habitualnom glasnoćom u trajanju jedne minute izmjerili porast vrijednosti $F_{0}$ i manji nagib spektralne ovojnice $L T A S-$-a. Kapec i Kovačić (2010) ispitivale su učinke 45-minutnog čitanja povišenim glasom u 9 mladih žena urednoga glasovnog statusa. Samoprocjenom je glasa nakon vokalnog opterećenja utvrđen vokalni zamor blagog i umjerenog stupnja te napetost glasa, a rezultati akustičke analize produžene fonacije vokala /a/ pokazali su bitno višu vrijednost $H N R$-a, te bitno nižu vrijednost jittera nakon eksperimentalnog zadatka što su autorice protumačile kao kompenzacijsku fonacijsku hiperfunkciju, a ne "bolji" glas. Kitch i sur. (1996) mjerili su pak učinke pjevačkog nastupa na uzorku 10 profesionalnih zborskih pjevača-tenora prosječne dobi 38,7 godina analizirajući niz uzoraka produžene fonacije vokala /a/ različitih tonskih visina i glasnoća prije i poslije koncertne izvedbe. U većine su ispitanika nakon koncerta utvrđeni akustički pokazate- lji pogoršanja vokalnog statusa: bitno više vrijednosti jittera na visokim tihim tonovima, ugodnoj i bazalnoj visini glasa, više vrijednosti shimmera na bazalnoj visini glasa, niža vrijednost $H N R$-a na ugodnoj visini glasa i visokim tihim tonovima. Kovačić (2002) je na uzorku 10 profesionalnih plesača-pjevača mjerila učinke radnog vremena i utvrdila da su bazalna visina glasa i HNR na najvišem mogućem tonu foniranja najosjetljivije varijable čije su vrijednosti nakon radnog vremena bile značajno više. Autorica ovu promjenu nije interpretirala kao poboljšanje vokalnoga statusa nego je vrijednosti početnog mjerenja povezala s jutarnjim glasom koji karakterizira najniža vrijednost bazalne visine glasa, a može se očekivati i niža vrijednost $H N R$-a i to uslijed opuštene laringalne muskulature, tj. neugrijanosti glasa pa je zaključila da se glasove trebalo snimati u još jednoj vremenskoj točki, onoj neposredno nakon ugrijavanja glasa temeljem koje učinak vokalnog zamora ne bi bio zamaskiran značajkama jutarnjega glasa. Istraživanje Laukkanen i sur. (2008) provedeno na 79 nastavnica čiji su uzorci tekućega govora i produžene fonacije vokala /a/ ugodnom glasnoćom te glasnoćom kojom bi se glasale u razredu analizirani prije i poslije radnog dana pokazalo je više vrijednosti $F_{0}, S P L$-a i omjera $\alpha$ na uzorcima govora te više vrijednosti $F_{0}$ i $S P L$-a na uzorcima fonacije uz istodobno niže vrijednosti jittera i shimmera.

Budući da vokalni zamor ponajviše pogađa vokalne profesionalce, u ovom se istraživanju proučavao na nastavnicama koje su nesumnjivo među najvećim "potrošačima" glasa što ih istodobno čini i najugroženijima kada se govori o vokalnom zdravlju.

\section{CILJ ISTRAŽIVANJA}

Cilj je istraživanja utvrditi akustičke značajke vokalnoga zamora nastavnica mjerenjem prosječnoga govornog $F_{0}$, omjera $H_{1} / H_{2}$ iz produžene fonacije vokala /a/ i spektralnih veličina iz dugotrajnog prosječnog spektra $L T A S$-a govora. Mjerenje $L T A S$-a odabrano je zato što je rad usredotočen na evaluaciju dugotrajnoga, kroničnog vokalnog zamora, a LTAS je ponajbolji objektivni prezentant (dugotrajne) kvalitete glasa. Mjeri se za uzorak tekućega govora koji sadrži bitno više informacija o kvaliteti glasa nego produžena fonacija vokala (npr. Schaeffer i Sidavi, 2010; Maryn i sur., 2010; Fourcin i Abberton, 2008; Bele, 2005; Eadie i Doyle, 2005; Halberstam, 2004). Stoga ga i za subjektivnu procjenu glasa preporučuje 
Odbor za fonijatriju Europskog udruženja laringologa (DeJonckere i sur., 2001). Unatoč tomu, spektralne se karakteristike vokalnoga zamora relativno malo istraživalo, i to uglavnom u uvjetima kratkotrajnog vokalnog opterećenja izazvanog u laboratorijskim uvjetima (npr. Laukkanen i sur., 2008; Rantala i sur., 1998; Novak i sur., 1991). Pritom se porast vrijednosti spektralnih veličina (omjer $\alpha$, relativnu spektralnu energiju po određenim područjima frekvencija) interpretiralo kao posljedičnu fonacijsku hiperfunkciju.

Rezultati ovog istraživanja usredotočeni su na mjerenje akustičkih značajki dugotrajnoga vokalnoga zamora. Doprinijet će rasvjetljavanju sindroma vokalnoga zamora uopće, biti korisni njegovoj kliničkoj evaluaciji, a mogli bi iznjedriti varijable bitne za logopedski probir glasa s ciljem (ranog) otkrivanja vokalnoga zamora.

\section{HIPOTEZA ISTRAŽIVANJA}

Postavljena je hipoteza $H_{1}$ prema kojoj postoje statistički značajne razlike $u$ akustičkim značajkama glasa između nastavnica s vokalnim zamorom i nastavnica bez vokalnoga zamora. U usporedbi s nastavnicama bez zamora, nastavnice s vokalnim zamorom imaju nižu vrijednost prosječnoga govornog $F_{0}$, niži $H_{1} / H_{2}$ te niže vrijednosti relativne jakosti najjačeg spektralnog vrha područja $0-5 \mathrm{kHz}$, omjera $\alpha$ i spektralne energije područja frekvencija 1-2 kHz, 2-3 kHz, 3-4 kHz i 4-5 kHz u odnosu na referentno područje $0-1 \mathrm{kHz}$.

\section{METODE RADA}

\section{Uzorak ispitanika}

U uzorku je ispitanika 50 nastavnica zaposlenih u osnovnim školama Grada Zagreba u punom radnom vremenu. Prosječna im je dob 40,8 $\pm 10,6$ godina (raspon: 24-60), a prosječna duljina nastavničkog radnog staža $15,7 \pm 10,8$ godina (raspon: 1-36). U istraživanju su sudjelovale dobrovoljno.

Uzorak nastavnica podijeljen je u dvije skupine. Kriterij podjele bio je broj subjektivnih simptoma vokalnoga zamora ispitan samoprocjenom simptoma vokalnoga zamora pa one nastavnice koje pate od triju ili više simptoma tvore skupinu nastavnica s vokalnim zamorom (u daljnjem tekstu VZ). Njih su 23. Ispitanice bez ijedne subjektivne smetnje, odno- sno s manje od tri simptoma tvore skupinu bez vokalnoga zamora (u daljnjem tekstu BVZ). Izbrojano ih je 27. Opisano formiranje uzoraka $u$ istraživanjima ove vrste nije neuobičajeno jer vrlo je malo nastavnica bez ijednog vokalnog simptoma (ovdje detektirano samo 6). Tablica 1 prikazuje frekvencije, odnosno postotke nastavnica s obzirom na broj simptoma.

Tablica 1. Frekvencije i postoci nastavnica po broju subjektivnih simptoma vokalnoga zamora

\begin{tabular}{|c|c|c|}
\hline $\begin{array}{c}\text { Broj } \\
\text { simptoma }\end{array}$ & $\begin{array}{c}\text { Frekvencija } \\
\text { (i postotak, \%) }\end{array}$ & $\begin{array}{c}\text { Kumulativna } \\
\text { frekvencija } \\
\text { (i postotak, \%) }\end{array}$ \\
\hline $0^{*}$ & $6(12)$ & $6(12)$ \\
\hline $1^{*}$ & $12(24)$ & $18(36)$ \\
\hline $2^{*}$ & $9(18)$ & $27(54)$ \\
\hline 3 & $10(20)$ & $37(74)$ \\
\hline 4 & $8(16)$ & $45(90)$ \\
\hline 5 & $3(6)$ & $48(96)$ \\
\hline 6 & 0 & $48(96)$ \\
\hline 7 & 0 & $48(96)$ \\
\hline 8 & $1(2)$ & $49(98)$ \\
\hline 9 & 0 & $49(98)$ \\
\hline 10 & $1(2)$ & $50(100)$ \\
\hline Ukupno & & \\
\hline
\end{tabular}

* Skupina BVZ

Nastavnice skupine VZ imaju prosječno po četiri simptoma vokalnoga zamora među kojima su najučestaliji promuklost, nadražajni kašalj, neugodan osjećaj u grlu i vratu (bol, napetost), produbljen glas i suhoća grla. Skupina BVZ ima u prosjeku po jedan simptom. Najčešće je to suhoća grla ili promuklost. (Detaljnu raspodjelu simptoma vokalnoga zamora v. u prilogu 1.) Tablica 2 pokazuje da se životnom dobi i duljinom radnog staža u nastavi skupine BVZ i VZ statistički bitno ne razlikuju što opravdava usporedbu njihovih rezultata. Nadalje, u skupini BVZ je 8 pušačica (30\%), a u VZ ih puši 9 (39\%). Vokalnim se hobijima (pjevanje, gluma, predavanje izvan radnog vremena...) u skupini BVZ bavi 7 nastavnica (26\%), a u VZ 4 (17\%).

\section{Uzorak varijabli}

Uzorak varijabli čine akustičke veličine mjerene iz uzoraka tekućega govora (čitanja) trajanja jedne minute i produžene fonacije vokala /a/ trajanja jedne sekunde. Uz kratak opis donosi ih tablica 3. 
Tablica 2. Univarijatne analize varijance dobi i nastavničkog radnog staža u nastavnica bez vokalnoga zamora $B V Z(N=27)$ i nastavnica s vokalnim zamorom $V Z(N=23)$

\begin{tabular}{|c|c|c|c|c|c|c|c|c|c|}
\hline \multirow[t]{2}{*}{ Varijabla } & \multicolumn{2}{|c|}{ BVZ } & \multicolumn{2}{|c|}{$\mathbf{V Z}$} & \multirow{2}{*}{$\begin{array}{c}\text { Wilksova } \\
\lambda\end{array}$} & \multirow[t]{2}{*}{ F-omjer } & \multicolumn{2}{|c|}{ DF } & \multirow[t]{2}{*}{$\mathbf{p}$} \\
\hline & M & SD & $\mathbf{M}$ & SD & & & 1 & 2 & \\
\hline Dob, godina & 38,6 & 9,81 & 43,30 & 11,08 & 0,950 & 2,505 & 1 & 48 & 0,120 \\
\hline Staž, godina & 13,9 & 9,69 & 17,78 & 11,93 & 0,969 & 1,561 & 1 & 48 & 0,218 \\
\hline
\end{tabular}

$\mathrm{M}=$ aritmetička sredina, $\mathrm{SD}=$ standardna devijacija, $\mathrm{DF}=$ stupnjevi slobode, $\mathrm{p}=$ vjerojatnost.

Tablica 3. Akustičke varijable

\begin{tabular}{|l|l|}
\hline $\begin{array}{l}\text { Varijabla, } \\
\text { mjerna jedinica }\end{array}$ & Opis \\
\hline$F_{0}, \mathrm{~Hz}$ & $\begin{array}{l}\text { prosječna govorna fundamentalna } \\
\text { frekvencija }\end{array}$ \\
\hline$L 0, \mathrm{~dB}$ & $\begin{array}{l}\text { relativna jakost najjačeg spektralnog } \\
\text { vrha područja } 0-5 \mathrm{kHz}\end{array}$ \\
\hline$H_{1} / H_{2}, \mathrm{~dB}$ & $\begin{array}{l}\text { prosječni omjer amplituda prvoga i } \\
\text { drugog harmonika }\end{array}$ \\
\hline$\alpha, \mathrm{dB}$ & $\begin{array}{l}\text { omjer } \alpha, \text { nagib spektralne ovojnice } \\
(0-5 \mathrm{kHz})\end{array}$ \\
\hline$\Delta 1, \mathrm{~dB}$ & $\begin{array}{l}\text { omjer spektralne energije područja } \\
1-2 \mathrm{kHz} \text { i } 0-1 \mathrm{kHz}\end{array}$ \\
\hline$\Delta 2, \mathrm{~dB}$ & $\begin{array}{l}\text { omjer spektralne energije područja } \\
2-3 \mathrm{kHz} \text { i } 0-1 \mathrm{kHz}\end{array}$ \\
\hline$\Delta 3, \mathrm{~dB}$ & $\begin{array}{l}\text { omjer spektralne energije područja } \\
3-4 \mathrm{kHz} \text { i } 0-1 \mathrm{kHz}\end{array}$ \\
\hline$\Delta 4, \mathrm{~dB}$ & $\begin{array}{l}\text { omjer spektralne energije područja } \\
4-5 \mathrm{kHz} \text { i } 0-1 \mathrm{kHz}\end{array}$ \\
\hline
\end{tabular}

Govorna fundamentalna frekvencija $F_{0}$ izračunata je automatski algoritmom ugrađenim u program PRAAT, v. 5.2.16 (Boersma i Weenink, 2011) koji se koristilo za obradu zvukovnih podataka, dok su za spektralne varijable $\left(L 0, \alpha, \Delta 1-4, H_{1} / H_{2}\right)$ napisane računalne naredbe ${ }^{1}$ prema kojima ih se računalo također automatski. Najjači spektralni vrh $L 0$ računalo se iz $L T A S$-a koji je postavljen tako da analizira uzorke zvuka po pojasevima širine $100 \mathrm{~Hz}$. Program je detektirao pojas u kojem je spektralna energija u području frekvencija $0-5 \mathrm{kHz}$ najviša, a prema izrazu:

$L 0=10 \log \frac{\bar{E}_{\max . b i n}(0 . .5 \mathrm{kHz})}{\bar{E}_{0-5 \mathrm{kHz}}}$

Nagib spektralne ovojnice $\alpha$ izražen je omjerom spektralne energije područja viših frekvencija (1-5 kHz) i nižih (0-1 kHz). Iskazuje dakle balans spektralne energije po frekvencijama za analizirani raspon frekvencija. Izračunat je na način kako su ga odredili Frøkjær-Jensen i Prytz (1976):

$$
\alpha=10 \log \frac{E_{1-5 \mathrm{kHz}}}{E_{0-1 \mathrm{kHz}}}
$$

Niz spektralnih varijabli delta $\Delta(\Delta 1, \Delta 2, \Delta 3 \mathrm{i}$ $\Delta 4)$ izražen je omjerom spektralnih energija područja viših frekvencija i područja $0-1 \mathrm{kHz}$ kao referentnog. To nalikuje računanju parametra $\alpha$ : varijable $\Delta$ mjere nagib spektra u pojasevima frekvencija širine $1000 \mathrm{~Hz}$ pri čemu su područja viših frekvencija čija se spektralna energija uspoređuje s referentnim pojasom frekvencija $(0-1 \mathrm{kHz})$ sljedeća:
a) $1-2 \mathrm{kHz}$, za računanje varijable $\Delta 1$
b) $2-3 \mathrm{kHz}$, za računanje varijable $\Delta 2$
c) $3-4 \mathrm{kHz}$, za računanje varijable $\Delta 3$
d) $4-5 \mathrm{kHz}$, za računanje varijable $\Delta 4$.

Takva metodologija u literaturi nije korištena. Sličan model u kojem je referentno područje frekvencija od $50 \mathrm{~Hz}$ do $1 \mathrm{kHz}$ s kojim se uspoređuju najjači spektralni vrhovi u pojasevima frekvencija širine tisuću herca za $L T A S$ raspona frekvencija 0-5 kHz koriste primjerice Laukkanen i sur. (2004b) skupno analizirajući glasove 6 djevojaka i 6 mladića, te Leino (2009) u mjerenju glasova 50 mladića.

Varijable $\Delta \mathrm{n}$ računalo se prema sljedećim izrazima:
a) $\Delta 1=10 \log \frac{\bar{E}_{1-2 k H z}}{\bar{E}_{0-1 k H z}}$
b) $\Delta 2=10 \log \frac{E_{2-3 k H z}}{\bar{E}_{0-1 k H z}}$
c) $\Delta 3=10 \log \frac{E_{3-4 k H z}}{\bar{E}_{0-1 k H z}}$
d) $\Delta 4=10 \log \frac{E_{4-5 \mathrm{kHz}}}{\bar{E}_{0-1 \mathrm{kHz}}}$

Omjer $H_{1} / H_{2}$ jedina je varijabla koju se računalo iz produžene fonacije vokala /a/. Izračunat je kao

1 Programiranje je obavio Ton Wempe, dipl. ing. sa Sveučilišta u Amsterdamu. 
omjer amplituda prvoga harmonika $H_{1}$ i drugog $H_{2}$ prema izrazu:

$$
H_{1} / H_{2}=10 \log \frac{\overline{H_{1}}}{\overline{H_{2}}}
$$

\section{Mjerni instrumenti}

\section{Samoprocjena subjektivnih simptoma vokalnoga zamora}

Za samoprocjenu subjektivnih simptoma vokalnoga zamora korišten je upitnik oblikovan za istraživanje, prilog 2. Osigurao je i temeljne podatke o ispitanicama kao što su životna dob, duljina radnog staža... Izvorno je sadržavao i druge čestice koje nisu u fokusu ovog istraživanja pa ih se u prilogu ne navodi.

\section{Snimanje i akustička analiza glasa}

Glasove se snimalo dinamičkim kardioidnim mikrofonom Electro Voice N/D157B i minidiskuređajem Sony $M Z-R 35$. Akustička je analiza glasova obavljena računalnim programom PRAAT, v. 5.2.16 (Boersma i Weenink, 2011).

\section{Provedba istraživanja}

Ispitanice su popunile upitnik kojim su prikupljeni temeljni podaci te podaci o subjektivnim simptomima vokalnoga zamora. Samoprocjenjivale su postojanje simptoma, ne i njihovu jakost. Slijedilo je pojedinačno snimanje uzoraka glasa u ugodnoj visini i glasnoći. To se obavljalo u tihim prostorijama osnovnih škola u kojima su ispitanice zaposlene, tijekom radnog vremena u jutarnjoj i poslijepodnevnoj smjeni. U jutarnjim se smjenama nikada nije snimalo na početku smjene kada glas nije zagrijan i može imati obilježja (rano)jutarnjega glasa, dok se u poslijepodnim smjenama pak nikada nije snimalo na kraju smjene čime se nastojalo izbjeći moguće posljedice akutnog vokalnog zamora. Fonirale su vokal /a/ po tri puta, a potom čitale zadani, isti tekst dva puta u trajanju od po 70-ak sekunda. Udaljenost mikrofona od usana ispitanica bila je $20 \mathrm{~cm}$. Za vrijeme snimanja su sjedile. Prije provedbe akustičke analize ujednačilo se razine zvučnoga tlaka svih uzoraka produžene fonacije $i$ govora tako da je srednja vrijednost razine zvuka iznosila 83,5 dB (0,3 Pa). Time je omogućena usporedba spektara dviju skupina nastavnica. (Rad se ne bavi mjerenjem apsolutnih vrijednosti razina spektralne energije.) Iz stacionarnog dijela signala triju uzoraka fonacije vokala /a/ izmjeren je prosječni $H_{1} / H_{2}$. Po jedan je uzorak tekućega govora trajanja 60 sekunda svake ispitanice podvrgnut analizi dugotrajnog prosječnog spektra $L T A S$-a. Analizirano je područje frekvencija $0-5 \mathrm{kHz}$ po pojasevima širine $100 \mathrm{~Hz}$ na temelju čega su izračunate vrijednosti spektralnih varijabli $(L 0$, omjer $\alpha$ i $\Delta 1-4)$ i prosječni govorni $F_{0}$.

\section{Metode obrade podataka}

Statistička obrada podataka provedena je primjenom statističkih paketa $R$ (R Development Core Team, 2011) i Statistica (StatSoft, Inc., 2011). Na manifestnoj su razini izračunati osnovni deskriptivni statistički parametri. Razlike između nastavnica s vokalnim zamorom i nastavnica bez vokalnog zamora u skupu akustičkih varijabli testirane su multivarijatnom analizom varijance i univarijatnom analizom varijance za pojedinačne varijable te diskriminativnom analizom (Morrison, 1990).

\section{REZULTATI I RASPRAVA}

\section{Temeljna statistička obrada}

\section{Skup akustičkih varijabli}

U računalnom programu PRAAT v. 5.2.16 (Boersma i Weenink, 2011) vrijednosti su spektralnih varijabli $\left(L 0, \alpha, \Delta 1-4 \mathrm{i} H_{1} / H_{2}\right)$ izmjerene automatski prema algoritmima oblikovanima za potrebe istraživanja (jedino je algoritam za računanje $F_{0}$ ugrađen u program korištene inačice) i ne postoji normativ njihovih vrijednosti (razni autori iznalaze različite načine računanja raspodjele spektralne energije, spektralne ravnoteže, mjera pada spektralne energije). Stoga će se vrijednosti tih varijabli interpretirati usporedbom rezultata $\mathrm{BVZ}$ i VZ skupine nastavnica što $i$ jest tema istraživanja. Podsjetiti treba na to da za zdravu kvalitetu glasa i ne postoji norma ili prosječna vrijednost spektralnog sadržaja, odnosno prosječna kontura spektralne ovojnice.

\section{Nastavnice bez vokalnoga zamora}

Temeljni statistički podaci za akustičke varijable nastavnica bez vokalnoga zamora sadržani 
Tablica 4. Vrijednosti osnovnih statističkih parametara akustičkih varijabli nastavnica bez vokalnoga zamora $(N=27)$

\begin{tabular}{|c|c|c|c|c|}
\hline Varijabla & Prosječna vrijednost $\mathbf{M}$ & Najniža vrijednost $\mathbf{M}_{\min .}$ & ${\text { Najviša vrijednost } \mathbf{M}_{\text {maks. }}}_{\text {Standardna devijacija SD }}$ \\
\hline$F_{0}$ & 193,51 & 145,52 & 221,65 & 16,82 \\
\hline$L 0$ & 12,01 & 9,87 & 14,53 & 1,17 \\
\hline$H_{1} / H_{2}$ & 7,22 & 1,46 & 18,91 & 3,52 \\
\hline$\alpha$ & $-14,84$ & $-19,88$ & $-10,91$ & 2,12 \\
\hline$\Delta 1$ & $-11,18$ & $-16,80$ & $-6,07$ & 2,44 \\
\hline$\Delta 2$ & $-16,10$ & $-20,47$ & $-13,12$ & 2,27 \\
\hline$\Delta 3$ & $-17,28$ & $-22,18$ & $-11,90$ & 2,98 \\
\hline$\Delta 4$ & $-22,70$ & $-27,92$ & $-16,90$ & 3,04 \\
\hline
\end{tabular}

su u tablici 4. Govorni je $F_{0}$ niži od prosječne vrijednosti ženskoga glasa. Vrijednošću 193,51 Hz u razredu je mezzosoprana. Rezultat je gotovo istovjetan onomu koji iznose Ilomäki i sur. (2008) za skupinu 60 nastavnica prosječne dobi 42 godine i radnog staža u nastavi 16 godina zdravoga glasa (prema samoprocjeni), a to je oko $193 \mathrm{~Hz}$, ili pak onomu iz istraživanja Laukkanen i sur. (2008) na uzorku 79 nastavnica jednake životne dobi koje su smatrale da nemaju poremećaj glasa ${ }^{2}: F_{0} \approx 191 \mathrm{~Hz}$. Lyberg Åhlander i sur. (2012) izmjerili su $199 \mathrm{~Hz}$ kao prosječnu vrijednost govornog $F_{0}$ nastavnica bez subjektivnih vokalnih simptoma $(\mathrm{N}=26$, $\mathrm{KD}=45$ god.). Podudarni su i rezultati Leppänen i sur. (2009) koji su u skupini 60 nastavnica bez poremećaja glasa ( $\mathrm{KD}=40,6$ god.) izračunali prosječni $F_{0} 190-195 \mathrm{~Hz}^{3}$ I japanski su autori Nishio i Niimi (2008) ispitujući promjene $F_{0}$ u funkciji životne dobi na uzorku žena bez laringalne patologije i vokalnih simptoma ustanovili da u životnoj dobi od 35 do 59 godina one govore prosječnim $F_{0} 196 \mathrm{~Hz}$.

Prosječna je vrijednost $H_{1} / H_{2} 7,22 \pm 3,52 \mathrm{~dB}$

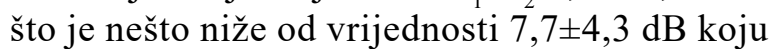
su izmjerili Holmberg i sur. (1995) također u uzorku zdravih žena $(\mathrm{N}=20)$, ili pak nešto više od vrijednosti $6,81 \pm 2,87 \mathrm{~dB}$ koju su utvrdili Kumar i sur. (2011) na uzorku 30 žena također zdravoga glasa životne dobi 20 do 40 godina.
Prosječna vrijednost omjera $\alpha$ gotovo je jednaka onoj koju iznose Ilomäki i sur. (2008) za 60 nastavnica prosječne dobi 42 godine i radnog staža u nastavi 16 godina, zdravoga glasa (prema samoprocjeni). Izmjerili su $-14,3 \pm 2,5$ dB. Leppänen i sur. (2009) utvrdili su prosječni omjer $\alpha$ vrijednosti od -13 do $-15 \mathrm{~dB}$ u skupini 60 zdravih nastavnica $(\mathrm{KD}=40,6)^{4}$, a Laukkanen i sur. (2008) $-15,10 \pm 2,07 \mathrm{~dB}$ na uzorku 77 nastavnica jednake životne dobi koje su svoj glas procijenile zdravim ${ }^{5}$ uz napomenu da se spomenuta vrijednost odnosi na uzorke govora snimane u 7,30 ujutro prije početka radne smjene. ${ }^{6}$ Torres da Silva i sur. (2011) također iznose sličnu prosječnu vrijednost omjera $\alpha$ $(-14,28 \pm 2,34 \mathrm{~dB})$ za uzorak žena prosječne dobi oko 27 godina.

Slika 1 prikazuje pojedinačne $L T A S$-e govora nastavnica bez vokalnoga zamora ucrtane u isti dijagram. Prosječan LTAS govora s ucrtanom regresijskom crtom pada spektralne energije po frekvencijama koja pokazuje stupanj nagiba spektralne ovojnice prikazuje dijagram na slici 2 . Uz prvi spektralni vrh koji odgovara nultom formantu $F 0$ uočava se i drugi spektralni vrh na oko $1,5 \mathrm{kHz}$ u području $F 2$. Iznad $2,5 \mathrm{kHz}$, u području viših formanta $F 3$ i $F 4$, spektralna je ovojnica blago uzdignuta i tvori široki klaster. Nema obilježja specijalnih formanata, primjerice govorničkog koji je

2 No, fonijatrijskim je pregledom utvrđeno da su 4 nastavnice vrlo promukle, da ih 18 ima zamjetnu promuklost, a ostale da su zdrave što upućuje na problem slabe vokalne osviještenosti tipične za većinu nastavnika.

$3 F_{0}$ je iskazan rasponom 190-195 Hz jer su ga autori mjerili u dvije subskupine zdravih žena u više vremenskih točaka kako bi ispitali učinke finske metode tzv. Vokalne masaže $e^{\mathrm{TM}}$ i poduke o higijeni glasa.

4 Naveden je raspon vrijednosti, a ne prosječna vrijednost. Objašnjenje stoji u prethodnoj fusnoti.

5 V. fusnotu broj 2.

6 Laukkanen i sur. (2008) su naime mjerili utjecaj radnog dana (kao vokalnog opterećenja) na glas nastavnica uspoređujući akustičke varijable, među kojima omjer $\alpha$, prije i poslije radnog vremena, dok se u ovom istraživanju nije željelo snimati glasove ujutro prije početka radnog vremena zbog učinka (rano)jutarnjega glasa koji kod nekih ljudi ima drugačiju kvalitetu nego ugrijan dnevni glas. 
karakteristika dobrih, kultiviranih govornih glasova. Pojedinačni su $L T A S$-i nastavnica bez zamora u prilogu 3.

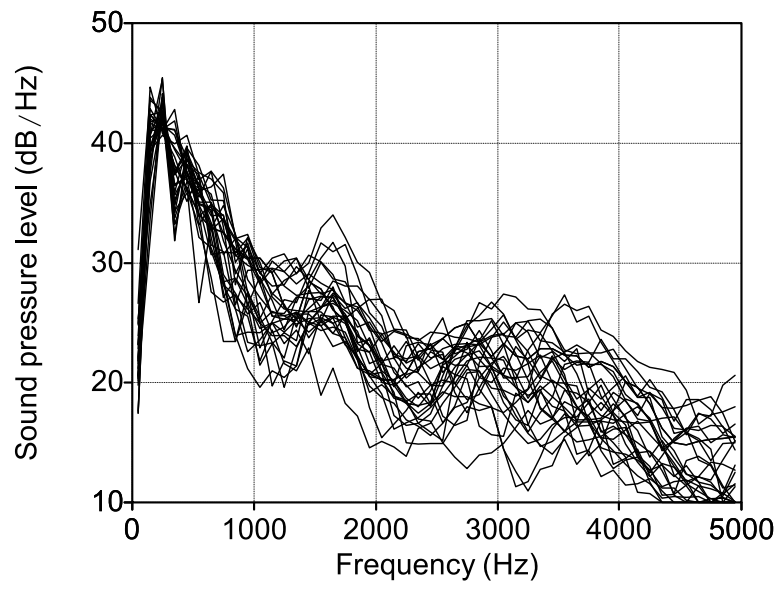

Slika 1. Pojedinačni LTAS-i govora nastavnica bez vokalnoga zamora $(N=27)$

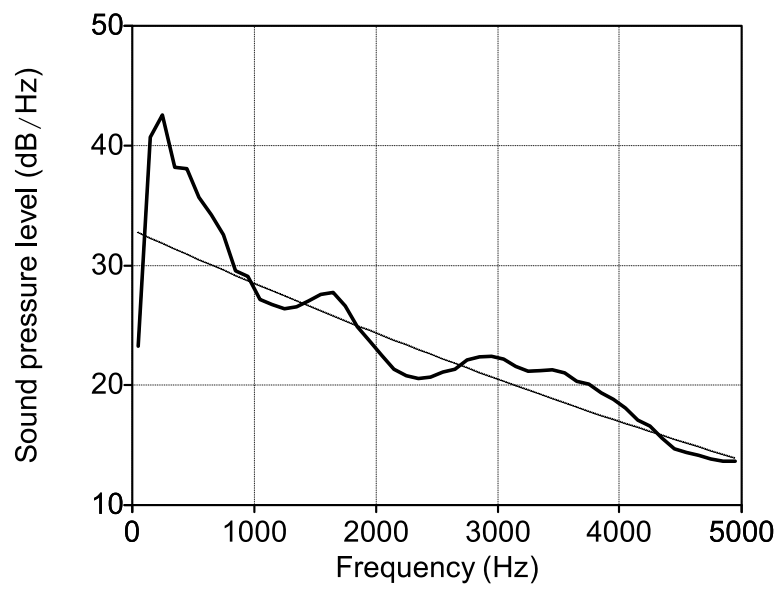

Slika 2. Prosječni LTAS govora i pripadajuća regresijska crta nastavnica bez vokalnoga zamora $(N=27)$

\section{Nastavnice s vokalnim zamorom}

Tablica 5 donosi temeljne statističke parametre akustičkih varijabli nastavnica s vokalnim zamorom. Ono što se najviše ističe jest vrijednost govornoga $F_{0} 176 \mathrm{~Hz}$. Bitno je ispod prosječnog raspona ženskoga glasa $200-220 \mathrm{~Hz}$, tj. u rangu je vrijednosti žena starije životne dobi za koje je karakterično spuštanje $F_{0}$ uslijed vokalne, ali i opće biološke deterioracije.

Primjerice Ma i Love (2010) su u skupini 11 žena prosječne životne dobi 70 godina izmjerile $F_{0}$ $171 \mathrm{~Hz}$ (istodobno u 12 mladih žena prosječne dobi 25 godina $197 \mathrm{~Hz}$ ). Torres da Silva i sur. (2011) utvrdili su u skupini 30 žena starije životne dobi (60-82 godine) prosječni govorni $F_{0} 188,84 \mathrm{~Hz}$. Nishio i Niimi (2008) izmjerili su sličnu vrijednost govornog $F_{0}$ za 55 ispitanica zdravoga glasa starijih od 60 godina, točnije $179 \mathrm{~Hz}$. Budući da su nastavnice u ovom istraživanju bitno mlađe od navedenih ispitanica s kojima dijele jednake vrijednosti $F_{0}$, nameće se zaključak da izmjerena vrijednost odražava disfunkciju. Niebudek-Bogusz i sur. (2006) također ističu da je prosječna vrijednost $F_{0}$ skupine 35 nastavnica (prosječne dobi 53,4 godine) s profesionalnim poremećajima glasa niža od prosječne vrijednosti $F_{0}$ zdravoga glasa. Za žene s vokalnim nodulima utvrdili su prosječnu vrijednost $F_{0} 185 \mathrm{~Hz}$, a za one sa sekundarnom vokalnom hipertrofijom $163 \mathrm{~Hz}$. Za zdrave glasove pak ističu $F_{0}$ prosječne vrijednosti $235 \mathrm{~Hz}$. Spomenuti treba i rezultate D'haeseleer i sur. (2011) koji su ispitivali akustička obilježja glasa žena u predmenopauzi ( $\mathrm{N}=22, \mathrm{KD}=48$ god.). Utvrdili su, uz ostalo, prosječni $F_{0} 184 \mathrm{~Hz}$, što je bitno niže od rezultata BVZ skupine mladih žena $(\mathrm{N}=22, \mathrm{KD}=22$ god.) za koje je izmjeren prosječni $F_{0} 200 \mathrm{~Hz}$. Valja dodati da su

Tablica 5. Vrijednosti osnovnih statističkih parametara akustičkih varijabli nastavnica s vokalnim zamorom $(N=23)$

\begin{tabular}{|c|c|c|c|c|}
\hline Varijabla & Prosječna vrijednost $\mathbf{M}$ & Najniža vrijednost $\mathbf{M}_{\text {min. }}$ & Najviša vrijednost $\mathbf{M}_{\text {maks. }}$ & Standardna devijacija SD \\
\hline$F_{0}$ & 175,88 & 147,60 & 222,18 & 20,96 \\
\hline$L 0$ & 12,00 & 9,49 & 14,05 & 1,16 \\
\hline$H_{1} / H_{2}$ & 6,52 & 1,26 & 12,41 & 3,38 \\
\hline$\alpha$ & $-15,34$ & $-18,66$ & $-12,10$ & 1,78 \\
\hline$\Delta 1$ & $-11,51$ & $-14,78$ & $-7,91$ & 1,98 \\
\hline$\Delta 2$ & $-16,32$ & $-19,64$ & $-11,84$ & 2,16 \\
\hline$\Delta 3$ & $-18,27$ & $-22,49$ & $-13,27$ & 2,36 \\
\hline$\Delta 4$ & $-23,86$ & $-28,01$ & $-20,58$ & 2,36 \\
\hline
\end{tabular}



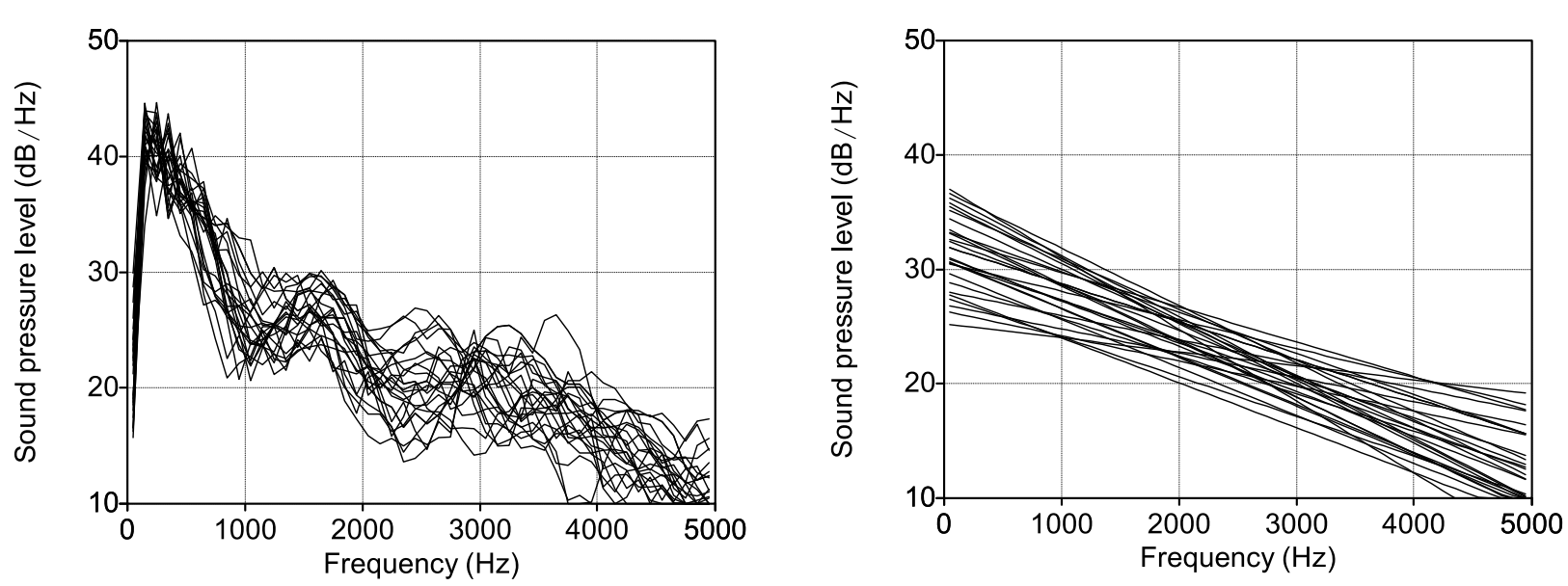

Slika 3. Pojedinačni LTAS-i govora nastavnica s vokalnim zamorom $(N=23)$

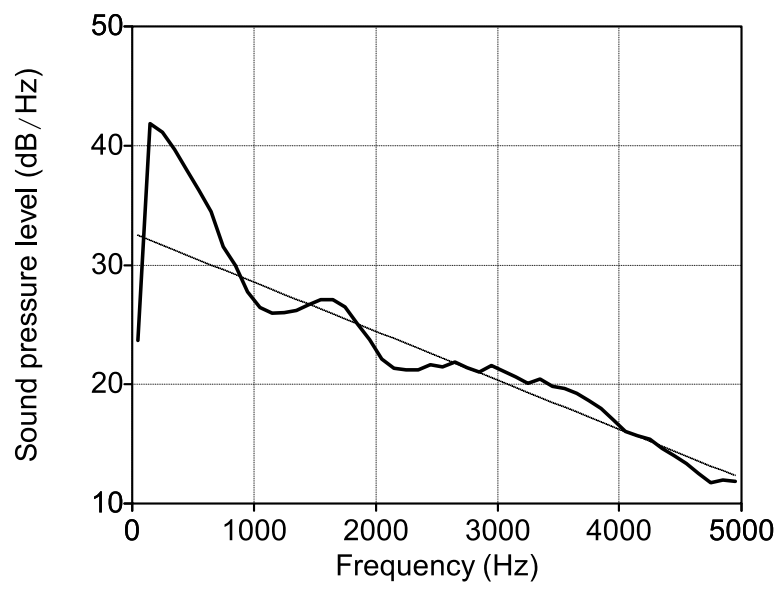

Slika 4. Prosječni LTAS govora i pripadajuća regresijska crta nastavnica s vokalnim zamorom $(N=23)$

u istraživanje bile uključene žene dobrog vokalnog i općeg zdravstvenog statusa. I Ferrand (2002) je, doduše na malim uzorcima ( 3 skupine po 14 ispitanica), utvrdila prosječni $F_{0}$ žena starijih od 70 godina $175 \mathrm{~Hz}$, a mladih (KD, raspon=21-34 god.) i onih u srednjoj dobi (KD, raspon=40-63 god.) $210 \mathrm{~Hz}$, odnosno $205 \mathrm{~Hz}$. Na temelju navedenih podataka, razvidno je da vrijednost prosječnog $F_{0}$ nastavnica s vokalnim zamorom ovog istraživanja odražava vokalno opterećenje profesije i posljedične promjene glasa uslijed vokalnog zamora koji ističu nizom simptoma, uz ostalo i produbljenim glasom. U skupini nastavnica VZ, deset (43,5\%) ih je istaknulo da ima "glas dublji nego inače", dok su u skupini nastavnica BVZ o istom simptomu izvijestile samo 3 ispitanice $(11,1 \%)$.

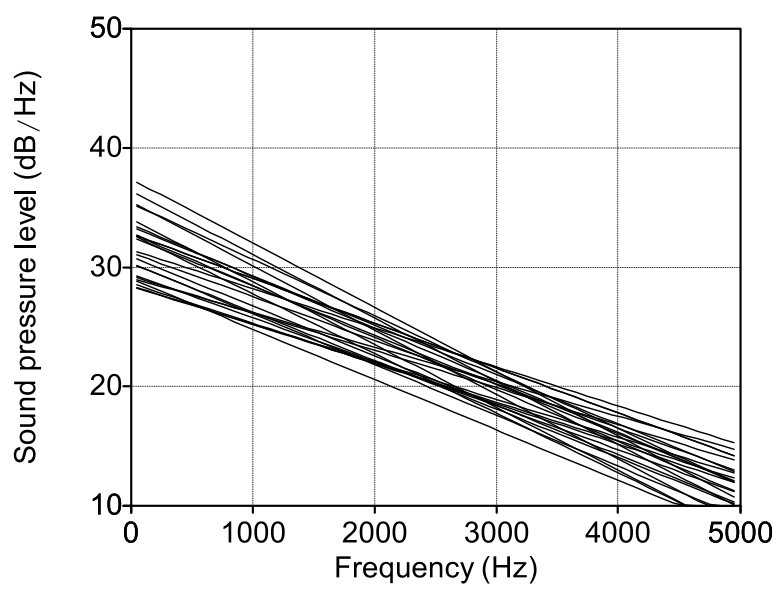

Slika 5. Nagibi spektralnih ovojnica prikazani regresijskim crtama i ucrtani u jedan dijagram: nastavnica bez vokalnoga zamora (gore) i nastavnica s vokalnim zamorom (dolje)

Slika 3 prikazuje pojedinačne $L T A S$-e govora nastavnica s vokalnim zamorom, a slika 4 njihov uprosječen dugotrajni prosječni spektar LTAS-a i pripadajuću regresijsku crtu koja obaviještava o nagibu spektralne ovojnice. Spektrom dominira prvi spektralni vrh u području $F 0$. Uočava se i drugi spektralni vrh u području $F 2$, dok u području frekvencija iznad $2 \mathrm{kHz}$ spektralna ovojnica nema markantnih uzdignuća. Pojedinačni su LTAS-i ovih nastavnica u prilogu 4.

Slike 5 prikazuje pojedinačne nagibe spektralnih ovojnica ucrtane u isti dijagram: nastavnica VZ i nastavnica BVZ, a slika 6 prosječan nagib spektralne ovojnice svake spomenute skupine. Usporednom analizom dijagrama uočava se da su rezultati nastavnica s vokalnim zamorom (VZ) manje raspršeni (što upućuje na sužavanje vokal- 

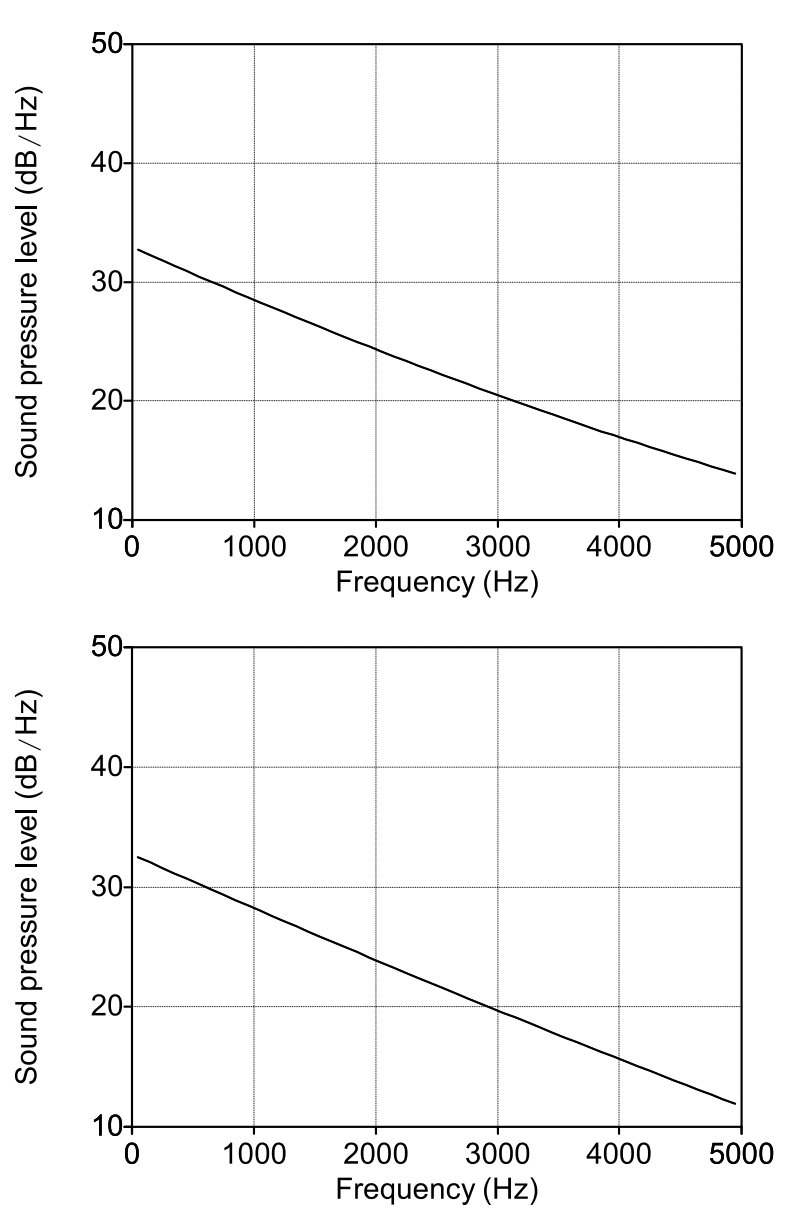

Slika 6. Prosječan nagib spektralne ovojnice prikazan regresijskom crtom: nastavnica bez vokalnoga zamora (gore) i nastavnica s vokalnim zamorom (dolje)

nog profila, manje bogatstvo kvalitete glasa) te da je prosječno opadanje spektralne energije veće nego u nastavnica bez zamora (BVZ), no jesu li te razlike i statistički značajne?

\section{Testiranje značajnosti razlika u prostoru akustičkih varijabli između nastavnica bez vokalnoga zamora i nastavnica s vokalnim zamorom}

Budući da se vokalni zamor opisuje nizom vokalnih simptoma, razumnim se čini očekivati njegove manifestacije i u akustičkim veličinama glasa što je izraženo u postavljenoj hipotezi istraživanja. Provjerena je multivarijatnom statističkom analizom varijance. Pokazala je da ne postoji statistički značajna razlika u skupu akustičkih varijabli između skupina $[F(8,41)=1,635 ; p=0,145]$. Rezultati univarijatnih analiza varijanci (Tablica 6) pokazali su statistički značajnu razliku samo na jednoj varijabli. To je govorni $F_{0}[F(1,48)=10,884$; $p=0,002]$, akustička veličina čija je vrijednost u skupini nastavnica s vokalnim zamorom bitno niža nego u nastavnica bez vokalnog zamora.

Zaključuje se da od svih mjerenih akustičkih varijabli jedino govorni $F_{0}$ oštro razlikuje skupine. Niska vrijednost $F_{0}$ dakle odražava vokalni zamor u skupini VZ i može se smatrati njegovom akustičkom značajkom. To je u skladu is rezultatima samoprocjene simptoma vokalnog zamora. U skupini VZ je 10 nastavnica $(43,5 \%)$ istaklo da im je glas dublji nego inače, dok su u skupini BVZ o istoj smetnji izvijestile samo 3 ispitanice $(11,1 \%)$, v. prilog 1 .

Hipoteza je testirana i kanoničkom diskriminativnom analizom. Željelo se razlučiti diskriminacijske varijable prema kojima se skupine nastavnica najviše razlikuju, odnosno utvrditi je li diskriminativna funkcija kao linearna kombinacija diskriminacijskih varijabli dobar klasifikator

Tablica 6. Univarijatne analize varijance akustičkih varijabli nastavnica bez vokalnoga zamora (BVZ) i nastavnica s vokalnim zamorom (VZ)

\begin{tabular}{|l|c|c|c|c|c|c|c|c|c|}
\hline \multirow{2}{*}{ Varijabla } & \multicolumn{2}{|c|}{ BVZ, N=27 } & \multicolumn{2}{c|}{ VZ, N=23 } & \multirow{2}{*}{ Vilksova } & \multirow{F}{*}{$\boldsymbol{F}$-omjer } & \multicolumn{2}{|c|}{ DF } & \multirow{2}{*}{$\boldsymbol{p}$} \\
\cline { 2 - 4 } & $\mathbf{M}$ & $\mathbf{S D}$ & $\mathbf{M}$ & $\mathbf{S D}$ & $\boldsymbol{\lambda}$ & & $\mathbf{1}$ & $\mathbf{2}$ & \\
\hline$F_{0}$ & 193,51 & 16,82 & 175,88 & 10,884 & 0,815 & 10,884 & 1 & 48 & 0,002 \\
\hline$L 0$ & 12,01 & 1,17 & 12,00 & 0,000 & 1,000 & 0,000 & 1 & 48 & 0,992 \\
\hline$H_{1} / H_{2}$ & 7,22 & 3,52 & 6,51 & 0,521 & 0,989 & 0,521 & 1 & 48 & 0,474 \\
\hline$\alpha$ & $-14,84$ & 2,12 & $-15,34$ & 0,815 & 0,983 & 0,815 & 1 & 48 & 0,371 \\
\hline$\Delta 1$ & $-11,18$ & 2,44 & $-11,51$ & 0,267 & 0,994 & 0,267 & 1 & 48 & 0,608 \\
\hline$\Delta 2$ & $-16,10$ & 2,27 & $-16,32$ & 0,113 & 0,998 & 0,113 & 1 & 48 & 0,738 \\
\hline$\Delta 3$ & $-17,28$ & 2,98 & $-18,27$ & 1,674 & 0,966 & 1,674 & 1 & 48 & 0,202 \\
\hline$\Delta 4$ & $-22,70$ & 3,04 & $-23,86$ & 2,210 & 0,956 & 2,210 & 1 & 48 & 0,144 \\
\hline
\end{tabular}

$\mathrm{M}=$ aritmetička sredina, $\mathrm{SD}=$ standardna devijacija, $\mathrm{DF}=$ stupnjevi slobode, $\mathrm{p}=$ =vjerojatnost.

Varijable na kojima se skupine nastavnica statistički značajno razlikuju istaknute su sivom pozadinom. 
skupina nastavnica što će pokazati i prosjeci diskriminativnih skorova skupina, centroidi. Rezultat spomenute obrade i centroidi skupina nastavnica na diskriminativnoj funkciji prikazani su u tablici 7. Izolirana diskriminativna funkcija nema diskriminativnu snagu $(p=0,143)$.

Tablica 7. Diskriminativna funkcija za skup akustičkih varijabli i centroidi skupina nastavnica bez vokalnoga zamora $B V Z$ is vokalnim zamorom $V Z$

\begin{tabular}{|c|c|c|}
\hline \multicolumn{2}{|l|}{ Funkcija } & 1 \\
\hline \multicolumn{2}{|c|}{ Svojstvena vrijednost } & 0,319 \\
\hline \multicolumn{2}{|c|}{ Varijanca, $\%$} & 100 \\
\hline \multicolumn{2}{|c|}{ Kanonička korelacija } & 0,492 \\
\hline \multicolumn{2}{|c|}{ Wilksova $\lambda$} & 0,758 \\
\hline \multicolumn{2}{|c|}{$\chi^{2}$} & 12,183 \\
\hline \multicolumn{2}{|l|}{ DF1 } & 8 \\
\hline \multicolumn{2}{|l|}{ DF2 } & 41 \\
\hline \multicolumn{2}{|l|}{$\mathrm{p}$} & 0,143 \\
\hline \multirow[t]{2}{*}{ Centroidi } & BVZ & 0,511 \\
\hline & $\mathrm{VZ}$ & $-0,600$ \\
\hline
\end{tabular}

Budući da je analiza varijance pokazala da je $F_{0}$ značajan pojedinačni diskriminator, ne čudi da u strukturi matrice dobivene funkcije (iako statistički nije značajna) spomenuta varijabla jedina ima visoko opterećenje (Tablica 8). S obzirom na iznesene rezultate statističkih obrada, postavljena se hipoteza odbacuje.

Tablica 8. Standardizirani koeficijenti varijabli kanoničke diskriminativne funkcije C i struktura kanoničke diskriminativne funkcije $S$

\begin{tabular}{|l|c|c|}
\hline \multirow{2}{*}{ Varijabla } & \multicolumn{2}{|c|}{ Diskriminativna funkcija } \\
\cline { 2 - 3 } & $\mathbf{C}$ & $\mathbf{S}$ \\
\hline$F_{0}$ & $\mathbf{1 , 0 6 3}$ & $\mathbf{0 , 8 7 4}$ \\
\hline$L 0$ & $-0,099$ & 0,003 \\
\hline$H_{1} / H_{2}$ & $-0,014$ & 0,211 \\
\hline$\alpha$ & 2,222 & 0,263 \\
\hline$\Delta 1$ & $-2,164$ & 0,151 \\
\hline$\Delta 2$ & $-0,087$ & 0,099 \\
\hline$\Delta 3$ & $-0,533$ & 0,373 \\
\hline$\Delta 4$ & 0,166 & 0,427 \\
\hline
\end{tabular}

Visoka su opterećenja $(r>0,30)$ istaknuta masnim znakovljem.

Niti Lyberg Åhlander i sur. (2012) nisu pronašli razlike u spektralnim karakteristikama glasa temeljenima na analizi $L T A S$-a, omjeru $\alpha$ i spektralnoj energiji područja viših frekvencija $5-8 \mathrm{kHz}$, no niti u fonetogramu i vrijednosti prosječnog $F_{0}$ između nastavnica bez vokalnih smetnji $(\mathrm{N}=26, \mathrm{KD}=45) \mathrm{i}$ onih sa smetnjama $(\mathrm{N}=26, \mathrm{KD}=49)$. Treba pripomenuti da je njihov kriterij formiranja skupina bila (samo)procjena izjave: "Imam problema s glasom.". U skupinu bez vokalnih smetnji uvrstili su one ispitanice koje nemaju problema s glasom ili se spomenuti problemi pojavljuju vrlo rijetko, dok su skupinu s vokalnim smetnjama tvorile one nastavnice koje katkad, često ili uvijek imaju vokalne simptome.

Moglo bi se promišljati bi li razlike između skupina bile veće i statistički značajne da su u skupini BVZ bile nastavnice bez ijednog simptoma zamora. Podsjetiti treba na to da su skupinu BVZ činile i one $\mathrm{s}$ jednim do dva simptoma, što nije neuobičajena praksa formiranja uzoraka ispitanika u istraživanjima ovog tipa (npr. Rantala i Vilkman, 1999). Ovdje je takva podjela učinjena nakon obuhvata nastavnica koje su bile zainteresirane sudjelovati u istraživanju, dakle, nije se znalo koliko će ih biti bez subjektivnih simptoma, niti se ciljano tražilo nastavnice bez ijednog simptoma vokalnoga zamora. Takva bi potraga bila teška jer je uistinu malo nastavnica koje bi zanijekale ijedan vokalni simptom. Uzorak je ispitanica-nastavnica bio prigodan uz napomenu da se kontaktiralo desetak osnovnih škola iz područja grada Zagreba od kojih je odabrano pet (kriterij je bila raspoloživost postorije u kojoj se glasove može snimati kvalitetno), a koje su god nastavnice tih škola iskazale želju za sudjelovanjem u istraživanju, uključene su u nj (samo je jedna nastavnica bila isključena zbog dijagnoze unilateralne paralize glasnica i teške disfonije). Od pedeset nastavnica koje su se odazvale, samo 6 ih je prema rezultatima samoprocjene vokalnih simptoma bilo zdravoga glasa, odnosno bez ijednog simptoma vokalnoga zamora. Analiza (poglavito multivarijatna) na tako maloj skupini ne bi bila smislena. Zbog toga je spomenuta skupina proširena i na one nastavnice koje iskazuju tek mali broj simptoma - jedan do dva, što se može smatrati gotovo normalnim statusom. Tako formiranu skupinu nastavnica "gotovo bez vokalnog zamora" u radu se radi preglednosti nazivalo "skupinom bez vokalnoga zamora".

\section{ZAKLJUČAK}

Vokalni se zamor temelji na samopercepciji povećanog laringalnog naprezanja i promjena 
kvalitete glasa. Može imati organsku i/ili funkcionalnu etiologiju: organska uključuje morfološke promjene koje izravno utječu na mehanizam fonacije (edemi i sl.), dok je u temelju funkcionalne neučinkovita upotreba glasa koja utječe kako na fonaciju, tako i na fiziologiju (McCabe i Titze, 2002). Pritom promjene mehanizma fonacije ne moraju biti čujne pa se postavlja pitanje mogu li ih dohvatiti sofisticirani alati akustičke analize i o kakvim je akustičkim značajkama riječ? Bio je to glavni motiv ovog istraživanja provedenog na uzorku nastavnica čije zanimanje predstavlja plodno tlo za pojavu i razvoj vokalnoga zamora budući da se temelji na vokalnom predoziranju i foniranju povišenim glasom. Utvrđivanje akustičkih značajki vokalnoga zamora omogućilo bi njegovo rano otkrivanje te pravovremenu, ranu intervenciju.

Postavljena je hipoteza prema kojoj postoje značajne razlike $u$ akustičkim varijablama glasa između nastavnica s vokalnim zamorom $(\mathrm{N}=23)$ i nastavnica bez vokalnoga zamora $(\mathrm{N}=27)$. Njihovi su glasovi (tekući govor i produžena fonacija vokala /a/) akustički analizirani u programu PRAAT. Skup akustičkih varijabli izmjerenih iz uzoraka govora sačinjavali su prosječni govorni $F_{0}$ i niz spektralnih veličina izmjerenih iz LTAS-a govora: jakost najjačeg spektralnog vrha $L 0$, omjer $\alpha$ te varijable $\Delta 1, \Delta 2, \Delta 3$ i $\Delta 4$ koje iskazuju omjer spektralnih energija područja viših frekvencija i to pojaseva $1-2 \mathrm{kHz}, 2-3 \mathrm{kHz}, 3-4 \mathrm{kHz}$ i $4-5 \mathrm{kHz}$ i referentnog područja frekvencija $0-1 \mathrm{kHz}$. Računao se i prosječni $H_{1} / H_{2}$ iz harmoničkog spektra triju uzoraka produžene fonacije vokala /a/. Hipoteza je testirana multivarijatnom i univarijatnim analizama varijance te diskriminativnom analizom.

Rezultati obrada pokazali su da ne postoje statistički značajne razlike u skupu akustičkih varijabli između skupina nastavnica. Postavljena je hipoteza odbačena. Međutim, kao pojedinačni se diskriminator izdvojio govorni $F_{0}$, veličina koja se pokazuje osjetljivom i u mjerenjima učinaka kratkotrajnog vokalnog opterećenja (npr. Lehto i sur., 2006; Laukkanen i sur., 2004a; Kovačić i sur., 2000; Rantala i sur., 1998). Prosječni je $F_{0}$ skupine BVZ 194 Hz, a skupine VZ 176 Hz. Posljednji je u rangu vrijednosti žena starije životne dobi ili pak onih s poremećajem glasa, što vokalni zamor jest. Ovaj nalaz usklađen je sa samoprocjenom simpto- ma vokalnoga zamora. Naime, gotovo svaka druga nastavnica sa zamorom istakla je produbljen glas kao subjektivnu smetnju.

Budući da je promuklost uobičajena subjektivna smetnja vokalnoga zamora, što je pokazalo i ovo istraživanje, vjerovalo se da će se odraziti na oblik spektralne ovojnice, te da će hipoteza biti potvrđena. No to se nije dogodilo. Moguće je da simptomi vezani za glas nisu bili dovoljno jaki da bi ih se akustički detektiralo. Može se postaviti i pitanje o formiranju skupina ispitanica koje se uspoređivalo: bi li rezultati bili drugačiji da se skupina nastavnica bez vokalnog zamora iznimno strogo formirala, tj. da su u nju uključene samo nastavnice bez ijednog simptoma. Takve je, doduše, teško pronaći (ovdje ih je detektirano samo šest), a dodatni je problem i činjenica da samoprocjena u kojoj se negira postojanje vokalnih simptoma ne znači da vokalnih problema u smislu akustičke manifestacije nema. Taj nesklad proizlazi iz slabe vokalne osviještenosti. Nadalje, treba podsjetiti i na utvrđen omjer vokalnih i tjelesnih simptoma koji možda najsnažnije objašnjava nepostojanje jasne akustičke slike glasova sa zamorom: u skupini VZ ustanovljen je omjer 55\%:45\%, a u skupini BVZ 43\%:57\%, dakle, gotovo je jednak broj vokalnih i tjelesnih simptoma. To uistinu komplicira akustičko mjerenje vokalnoga zamora (tjelesni će se simptomi vokalnoga zamora teško odraziti na kvalitetu akustičkoga signala glasa) jer akustička analiza nije alat koji može izmjeriti "osjećaj nečega" (boli i sličnih neugodnih senzacija) u grlu ili ostalim dijelovima tijela. Jasno to ističe Kotby (1995) kada izvještava o slučajevima vokalnoga zamora kod kojih se laringoskopskim pregledom ne uočavaju bitne morfološke promjene na larinksu zaključujući da se radi o "disfoniji" koju pacijent više osjeća u grlu nego što je čuje u vlastitu glasu. I Vilkmanovo (2004) isticanje vokalnog zamora kao subjektivne pojave, nečega što pobuđuje neugodne senzacije vezane za fonaciju ne djeluje ohrabrujuće kada je riječ o fonometriji vokalnoga zamora.

Razmišljajući o dobivenim vrijednostima spektralnih varijabli, zamisao o mjerenju drugih veličina zavređuje pozornost. Bi li rezultati bili drugačiji da se proširilo ukupno područje frekvencija koje se analiziralo, da se uvelo više varijabli $\Delta$ koje bi kao područja viših frekvencija koja se uspoređu- 
je s referentnim područjem $(0-1 \mathrm{kHz})$ uključivalo pojaseve $5-6 \mathrm{kHz}, 6-7 \mathrm{kHz}, 7-8 \mathrm{kHz}, 8-9 \mathrm{kHz}$, 9-10 kHz? Naime, eksperimenti su pokazali da područja tako visokih frekvencija oštro diskriminiraju disfonične šumne glasove od zdravih. Shoji i sur. (1992) kao kritično ističu područje oko $6 \mathrm{kHz}$, Rihkanen i sur. (1994) područje oko 8 kHz, a Naranjo i sur. (1994) idu korak dalje iznalazeći da se zdravi i promukli glasovi umnogome razlikuju ne samo u području 6-10 kHz, nego čak i u području $10-16 \mathrm{kHz}$. U tom dijelu spektra nalaze da su promukli glasovi pojačani. Izneseno upućuje na to da postoje mjerljive promjene kvalitete glasa uslijed vokalnoga zamora i tu bi zamisao valjalo provjeriti analizom šireg područja frekvencija.

Zaključak je ovoga rada da je akustička značajka vokalnoga zamora ispodprosječna vrijednost govornoga $F_{0}$, no i da akustička analiza govora primjenom metode $L T A S$, učinjena za područje frekvencija $0-5 \mathrm{kHz}$, ne može detektirati vokalni zamor. Nadalje, akustička mjerenja vokalnoga zamora treba nastaviti s ciljem iznalaženja najosjetljivijih akustičkih veličina ili baterije fonometrijskih testova koja će tu pojavu uspješno detektirati. A do tada, ili prije svega, treba (početi) raditi na osvještavanju i prevenciji tog profesionalnog problema uvođenjem vokalne edukacije $u$ obrazovanje svih budućih vokalnih profesionalaca. Vokalna je osviještenost osobit problem (Kovacic, 2005). Činjenica je da upravo zbog vokalne neosviještenosti i neznanja mnogi vokalni profesionalci ne registriraju vlastite promjene kvalitete glasa $\mathrm{i} / \mathrm{ili}$ ih zanemaruju. Pokazalo je to primjerice istraživanje De Jonga i sur. (2003) u kojem je temeljem tzv. psihološkoga kaskadnog modela otkriveno 39\% nastavnika nesvjesnih vlastitog poremećaja glasa od ukupno 76 ispitanih. Laukkanen i sur. (2008) su pak na uzorku 79 nastavnica, koje su vlastiti glas smatrale zdravim, fonijatrijskim pregledom dijagnosticirali 4 vrlo promukle nastavnice i 18 nastavnica sa zamjetnom promuklošću. Uz vokalno osviještavanje, nastavnicima i drugim vokalnim profesionalcima potrebna su temeljna znanja o organima za proizvodnju glasa, pravilnom korištenju glasa, brizi za glas, metodama samopomoći, obaviještenost o tome komu se obratiti kada se pojave prvi vokalni simptomi i vježbe za glas. 


\section{LITERATURA:}

Bele, I. V. (2005): Reliability in perceptual analysis of voice quality. Journal of Voice 19, 4, 555-573.

Blaži, D., Heđever, M. (2010): Somatske teškoće kao indikatori stresa i teškoće glasa kod odgojiteljica i nastavnika. Hrvatska revija za rehabilitacijska istraživanja 46, 2, 19-33.

Boersma, P., Weenink, D. (2011): PRAAT - doing phonetics by computer [računalni program]. Version 5.2.16, URL: http://www.praat.org/

D’haeseleer, E. Depypere, H., Claeys, S., Wuyts, F. L., Baudonck, N., Van Lierde, K. M. (2011): Vocal characteristics of middle-aged premenopausal women. Journal of Voice 25, 3, 360-366.

De Jong, F. I. C. R. S., Cornelis, B. E., Wuyts, F. L., Kooijman, P. G. C., Schutte, H. K., Oudes, M. J., Graamans, K. (2003): A psychological cascade model for persisting voice problems in teachers. Folia Phoniatrica Et Logopaedica $55,2,91-101$.

Dejonckere, P. H., Bradley, P., Clemente, P., Cornut, G., Crevier-Buchman, L., Friedrich, G., Van de Heyning, P., Remacle, M., Woisard, V. (2001): A basic protocol for functional assessment of voice pathology, especially for investigating the efficacy of (phonosurgical) treatments and evaluating new assessment techniques - guideline elaborated by the Committee on phoniatrics of the European laryngological society (ELS). European Archives of Otorhinolaryngology 258, 2, 77-82.

Eadie, T. L., Doyle, P. C. (2005): Classification of dysphonic voice: acoustic and auditory-perceptual measures. Journal of Voice 19, 1, 1-14.

Eustace, C. S., Stemple, J. C., Lee, L. (1996): Objective measures of voice production in patients complaining of laryngeal fatigue. Journal of Voice 10, 2, 146-154.

Ferrand, C. T. (2002): Harmonics-to-noise ratio: an index of vocal aging. Journal of Voice 16, 4, 480-487.

Fourcin, A., Abberton, E. (2008): Hearing and phonetic criteria in voice measurement: clinical applications. Logopedics - Phoniatrics - Vocology 33, 1, 35-48.

Frøkjær-Jensen, B., Prytz, S. (1976): Registration of voice quality. Bruel \& Kjær Technical Review 3, 3-17.

Halberstam, B. (2004): Acoustic and perceptual parameters relating to connected speech are more reliable measures of hoarseness than parameters relating to sustained vowels. ORL - Journal for Oto-Rhino-Laryngology \& its Related Specialties 66, 2, 70-73.

Holmberg, E. B., Hillman, R. E., Perkel, J. S., Guiod, P. C., Goldman, S. L. (1995): Comparison among aerodynamic, elektroglottographic, and acoustic spectral measures of female voice. Journal of Speech and Hearing Research $38,6,1212-1223$.

Hunter, E. J., Titze, I. R. (2009): Quantifying vocal fatigue recovery: dynamic vocal recovery trajectories after a vocal loading exercise. Annals of Otology, Rhinology \& Laryngology 118, 6, 449-460.

Ilomäki, I., Laukkanen, A.-M., Leppänen, K., Vilkman, E. (2008): Effects of voice training and voice hygiene education on acoustic and perceptual speech parameters and self-reported vocal well-being in female teachers. Logopedics - Phoniatrics - Vocology 33, 2, 83-92.

Ilomäki, I., Leppänen, K., Kleemola, L., Tyrmi, J., Laukkanen, A.-M., Vilkman, E. (2009): Relationships between self-evaluations of voice and working conditions, background factors, and phoniatric findings in female teachers. Logopedics - Phoniatrics - Vocology 34, 1, 20-31.

Jackson, C. (1940): Myasthenia laryngis - observations on the larynx as an air column instrument. Archives of Otolaryngology - Head \& Neck Surgery 32, 3, 434-464.

Johnson, A. F. (1994): Disorders of speaking in the professional voice user. U: Benninger, M. S., Jacobson, B. H., Johnson, A. F. (ur.): Vocal arts medicine - the care and prevention of professional voice disorders. Thieme Medical Publishers, Inc., New York, 153-163. 
Kapec, K., Kovačić, G. (2010): Vokalno opterećenje: samoprocjena i akustički parametri glasa prije i poslije 45-minutnog čitanja povišenim glasom. U: Mildner, V., Liker, M. (ur.): Proizvodnja i percepcija govora, Odsjek za fonetiku Filozofskog fakultet Sveučilišta u Zagrebu, Odjel za fonetiku Hrvatskog filološkog društva, FF-press, Zagreb, 58-72.

Kitch, J. A., Oates, J. (1994): The perceptual features of vocal fatigue as self-reported by a group of actors and singers. Journal of Voice 8, 3, 207-214.

Kitch, J. A., Oates, J., Greenwood, K. (1996): Performance effects on the voices of 10 choral tenors: acoustic and perceptual findings. Journal of Voice 10, 3, 217-227.

Kostyk, B. E., Rochet, A. P. (1998): Laryngeal airway resistance in teachers with vocal fatigue: a preliminary study. Journal of Voice 12, 3, 287-299.

Kotby, M. N. (1995): The Accent method of voice therapy. Singular Publishing Group, Inc., San Diego, California.

Kovacic, G. (2005): Voice education in teacher training: an investigation into the knowledge about the voice and voice care in teacher-training students. Journal of Education for Teaching 31, 2, 87-97.

Kovačić, G. (2002): Utjecaj radnog dana na glas profesionalnih plesača-pjevača: akustička analiza glasa prije i poslije radnog vremena. Hrvatska revija za rehabilitacijska istraživanja 38, 2, 145-158.

Kovačić, G. (2003): Subjective voice complaints among schoolteachers. Symposium book De stem in het onderwijs - multidimensionaal-multidisciplinair. UMC St Radboud, Nijmegen, 99-111.

Kovačić, G., Heđever, M. i Buđanovac, A. (2000): Utjecaj vokalne probe na akustičke karakteristike glasa profesionalnih pjevačica. Hrvatska revija za rehabilitacijska istraživanja 36, 2, 137-144.

Kumar, B. R., Bhat, J. S., Mukhi, P. (2011): Vowel harmonic amplitude differences in persons with vocal nodules. Journal of Voice $25,5,559-561$.

Laukkanen, A.-M., Ilomäki, I., Leppänen, K., Vilkman, E. (2008): Acoustic measures and self-reports of vocal fatigue by female teachers. Journal of Voice 22, 3, 283-289.

Laukkanen, A.-M., Järvinen, K., Artkoski, M., Waaramaa-Mäki-Kulmala, T., Kankare, E., Sippola, S., Syrjä, T. i Salo, A. (2004a): Changes in voice and subjective sensations during a 45-min vocal loading test in female subjects with vocal training. Folia Phoniatrica et Logopaedica 56, 6, 335-346.

Laukkanen, A.-M., Syrjä, T., Laitala, M., Leino, T. (2004b): Effects of two-month vocal exercising with and without spectral biofeedback on student actors' speaking voice. Logopedics - Phoniatrics - Vocology 29, 2, 66-76.

Lauri, E.-R., Alku, P., Vilkman, E., Sala, E., Sihvo, M. (1997): Effects of prolonged oral reading on time-based glottal flow waveform parameters with special reference to gender differences. Folia Phoniatrica 49, 5, 234-246.

Lehto, L., Laaksonen, L., Vilkman, E., Alku, P. (2006): Occupational voice complaints and objective acoustic measurements - do they correlate? Logopedics - Phoniatrics - Vocology 31, 4, 147-152.

Leino, T. (2009): Long-term average spectrum in screening of voice quality in speech: untrained male university students. Journal of Voice 23, 6, 671-676.

Leppänen, K., Laukkanen, A.-M., Ilomäki, I., Vilkman, E. (2009): A comparison of the effects of Voice massageTM and voice hygiene lecture on self-reported vocal well-being and acoustic and perceptual speech parameters in female teachers. Folia Phoniatrica et Logopaedica 61, 4, 227-238.

Lyberg Åhlander, V., Rydell, R., Löfqvist, A. (2012): How do teachers with self-reported voice problems differ from their peers with self-reported voice health? Journal of Voice 26, 4, 149-161.

Ma, E. P.-M., Love, A. L. (2010): Electroglottographic evaluation of age and gender effects during sustained phonation and connected speech. Journal of Voice 24, 2, 146-152.

Maryn, Y., Corthals, P., Van Cauwenberge, P., Roy, N., De Bodt, M. (2010): Toward improved ecological validity in the acoustic measurement of overall voice quality: combining continuous speech and sustained vowels. Journal of Voice 24, 5, 540-555. 
McCabe, D. J., Titze, I. R. (2002): Chant therapy for treating vocal fatigue among public schoolteachers: a preliminary study. American Journal of Speech-Language Pathology 11, 356-369.

Morrison, D. F. (1990): Multivariate statistical methods, 3. izdanje. McGraw-Hill, Inc., New York.

Munier, C., Farrell, R. (2016): Working conditions and workplace barriers to vocal health in primary school teachers. Journal of Voice 30, 1, 127.e31-127.e41. DOI: http://dx.doi.org/10.1016/j.jvoice.2015.03.004

Naranjo, N. V., Mendoza Lara, E., Rodríguez, I. M., Carballo García, G. (1994): High-frequency components of normal and dysphonic voice. Journal of Voice 8, 2, 157-162.

Niebudek-Bogusz, E., Fiszer, M., Kotylo, P., Sliwinska-Kowalska, M. (2006): Diagnostic value of voice acoustic analysis in assessment of occupational voice pathologies in teachers. Logopedics - Phoniatrics - Vocology 31, 3, 100-106.

Nishio, M., Niimi, N. (2008): Changes in speaking fundamental frequency characteristics with aging. Folia Phoniatrica et Logopaedica 60, 3, 120-127.

Novak, A., Dlouha, O., Capkova, B., Vohradnik, M. (1991): Voice fatigue after theater performance in actors. Folia Phoniatrica 43, 2, 74-78.

R Development Core Team (2011): R - a language and environment for statistical computing. Vienna: R Foundation for Statistical Computing. URL: http://www.R-project.org/ (pristupljeno i arhivirano 3. veljače 2012.)

Rantala, L., Paavola, L., Körkkö, P., Vilkman, E. (1998): Working-day effects on the spectral characteristics of teaching voice. Folia Phoniatrica et Logopaedica 50, 4, 205-211.

Rantala, L., Vilkman, E. (1999): Relationship between subjective voice complaints and acoustic parameters in female teachers' voices. Journal of Voice 13, 4, 484-495.

Rihkanen, H., Leinonen, L., Hiltunen, T., Kangas, J. (1994): Spectral pattern recognition of improved voice quality. Journal of Voice 8, 4, 320-326.

Schaeffer, N., Sidavi, A. (2010): Toward a more quantitative measure to assess severity of dysphonia: preliminary observations. Journal of Voice 24, 5, 556-563.

Shoji, K., Regenbogen, E., Daw Yu, J., Blaugrund, S.M. (1992): High-frequency power ration of breathy voice. Laryngoscope 102, 3, 267-271.

StatSoft, Inc. (2011): Electronic statistics textbook. StatSoft, Tulsa. URL: http://www.statsoft.com/textbook/ (pristupljeno i arhivirano 3. veljače 2012.)

Torres da Silva, P., Master, S., Andreoni, S., Pontes, P., Ramos, L. R. (2011): Acoustic and long-term average spectrum measures to detect vocal aging in women. Journal of Voice 25, 4, 411-419.

Vilkman, E. (2004): Occupational safety and health aspects of voice and speech professions. Folia Phoniatrica et Logopaedica 56, 4, 220-253.

Welham, N. V., Maclagan, M. A. (2004): Vocal fatigue in young trained singers across a solo performance: a preliminary study. Logopedics Phoniatrics Vocology 29, 1, 3-12.

Zehmisch, H., Siegert, C., Wendler, J. (1979): Deutschland bis 1945. U: Wendler, J. (ur.): 75 Jahre Phoniatrie, Festschrift zu Ehren von Hermann Gutzmann, sen., Humboldt-Universität, Berlin, 11-27.

\section{NAPOMENA:}

Autorice se zahvaljuju britanskoj zakladi Frankopan koja je stipendiravši prvu autoricu omogućila provedbu istraživanja. 


\section{ACOUSTIC CHARACTERISTICS OF VOCAL FATIGUE}

Summary: Vocal fatigue is characterized by self-perceived increased laryngeal strain and voice quality changes. The condition can have organic or/and functional causes. Typically, it affects vocal professionals, and teachers are most numerous among them. Despite great number of studies, many questions about vocal fatigue such as its acoustic characterstics are still open. The hypothesis of the present study conducted on female teachers was that there are significant differences in acoustic variables between vocally fatigued teachers $(N=23)$ and teachers without it $(N=27)$. Running speech and prolonged phonation of the vowel /a/ were analyzed in PRAAT software calculating the long-term average speech spectrum LTASS and harmonic spectrum. The average speech $F_{0}$ and series of spectral variables were calculated: the strength of the strongest spectral peak $L_{0}$, the $\alpha$ ratio of the level difference above and bellow $1 \mathrm{kHz}$ for the 0-5 $\mathrm{kHz}$ range analyzed, and the variables $\Delta 1, \Delta 2, \Delta 3$ and $\Delta 4$ showing the ratios of the respective spectral energy bands of $1-2 \mathrm{kHz}, 2-3 \mathrm{kHz}, 3-4 \mathrm{kHz}$ and $4-5 \mathrm{kHz}$ relative to the $0-1 \mathrm{kHz}$ reference. The average $\mathrm{H}_{1} / \mathrm{H}_{2}$ ratio based on harmonic spectrum of three samples of the prolonged vowel /a/ production was calculated as well. The hypothesis was tested by multivariate and univariate analyzes of variance and discriminant analysis. The results showed that there are no significant differences in the set of acoustic variables between the two teacher groups, thus the hypothesis was rejected. However, the average speech $F_{0}$ showed to be strong single discriminator. Its mean value in the group of teachers with vocal fatigue, that is $176 \mathrm{~Hz}$, suggests dysfunction. Several factors may explain the absence of acoustic differences between the two groups, one of the most compelling of which is the fact that both groups reported similar numbers of subjective vocal and physical complaints. The results confirm the complex phenomenology of vocal fatigue syndrome, and suggest that acoustic analysis may have limited power to detect it.

Key words: vocal fatigue, acoustic analysis, long-term average spectrum LTAS, speech F0, teachers

\section{PRILOG 1}

Tablica 1. Suma opservacija subjektivnih simptoma vokalnoga zamora u skupini nastavnica BVZ (N=27) $i$ skupini nastavnica $\mathrm{VZ}(\mathrm{N}=23)$

\begin{tabular}{|c|c|c|c|c|}
\hline \multicolumn{3}{|c|}{ Subjektivni simptomi vokalnoga zamora } & BVZ & $\mathbf{V Z Z}$ \\
\hline \multirow{8}{*}{ 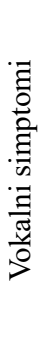 } & \multicolumn{2}{|l|}{ promuklost (hrapav glas) } & 5 & 16 \\
\hline & \multicolumn{2}{|l|}{ slab (tih) glas } & 1 & 3 \\
\hline & \multicolumn{2}{|l|}{ gubitak glasa } & 0 & 5 \\
\hline & \multicolumn{2}{|l|}{ nestabilan glas (s promjenama visine) } & 1 & 6 \\
\hline & \multicolumn{2}{|l|}{ glas dublji nego inače } & 3 & 10 \\
\hline & \multicolumn{2}{|l|}{ glas viši nego inače } & 0 & 0 \\
\hline & \multicolumn{2}{|l|}{ pucanje glasa } & 0 & 7 \\
\hline & \multicolumn{2}{|l|}{ šuman glas } & 1 & 0 \\
\hline \multirow{7}{*}{ 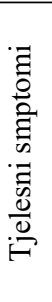 } & \multicolumn{2}{|l|}{ neugodan osjećaj u grlu i vratu (bol, napetost...) } & 1 & 11 \\
\hline & \multicolumn{2}{|l|}{ suhoća grla } & 9 & 9 \\
\hline & \multicolumn{2}{|l|}{ bol ili osjećaj zategnutosti i stisnutosti grla } & 2 & 4 \\
\hline & \multicolumn{2}{|l|}{ kratak dah } & 2 & 3 \\
\hline & \multicolumn{2}{|l|}{ poteškoće u održanju dovoljno glasnoga glasa } & 2 & 5 \\
\hline & \multicolumn{2}{|l|}{ potreba za kašljanjem zbog nadraženosti grla } & 3 & 14 \\
\hline & \multicolumn{2}{|l|}{ bol prilikom gutanja } & 0 & 2 \\
\hline \multirow{2}{*}{\multicolumn{2}{|c|}{ Vokalni simptomi }} & Ukupan broj & 13 & 52 \\
\hline & & Prosječan broj & 0,48 & 2,26 \\
\hline \multirow{2}{*}{\multicolumn{2}{|c|}{ Tjelesni simptomi }} & Ukupan broj & 17 & 43 \\
\hline & & Prosječan broj & 0,63 & 1,87 \\
\hline \multirow{2}{*}{\multicolumn{2}{|c|}{ Svi simptomi }} & Ukupan broj & 30 & 95 \\
\hline & & Prosječan broj & 1,11 & 4,13 \\
\hline
\end{tabular}




\section{PRILOG 2}

Upitnik kojim su prikupljani temeljni podaci i podaci o subjektivnim simptomima vokalnog zamora

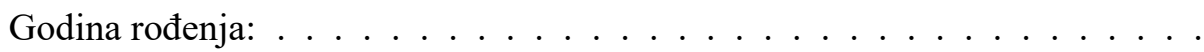

Spol (zaokružite) $\ldots \ldots \ldots \ldots \ldots \ldots \ldots \ldots \ldots \ldots \ldots \ldots \ldots$

Koliko ste godina zaposleni kao nastavnik? . . . . . . . . . . . . .

Koliko sati predajete tjedno?

Bavite li se još nekom govorničkom ili pjevačkom aktivnošću izvan nastave

(voditelj tečaja, zborovođa, gluma i slično)? Zaokružite odgovor. . . . . . . . . . . . . DA - NE

Konzumirate li cigarete? Zaokružite odgovor.. . . . . . . . . . . . DA - POVREMENO - NE

Imate li neke od sljedećih problema? Dobro razmislite i zaokružite jedan ili više odgovora.

- promuklost (hrapav glas)

- slab (tih) glas

- gubitak glasa

- nestabilan glas (s promjenama visine)

- glas dublji nego inače

- glas viši nego inače

- pucanje glasa (iznenadni gubici glasa usred riječi)

- šuman glas

- neugodan osjećaj u grlu i vratu (bol, napetost, umor)

- suhoća grla

- bol ili osjećaj zategnutosti i stisnutosti grla

- kratak dah (isprekidan govor zbog brzog istjecanja zraka i potrebe za novim dahom)

- poteškoće u održanju dovoljno glasnoga glasa

- potreba za kašljanjem zbog nadraženosti grla (uzrok nije prehlada)

- bol prilikom gutanja

Datum popunjavanja upitnika: 


\section{PRILOG 3}

Pojedinačni dugotrajni prosječni spektri govora nastavnica bez vokalnog zamora, $N=27$
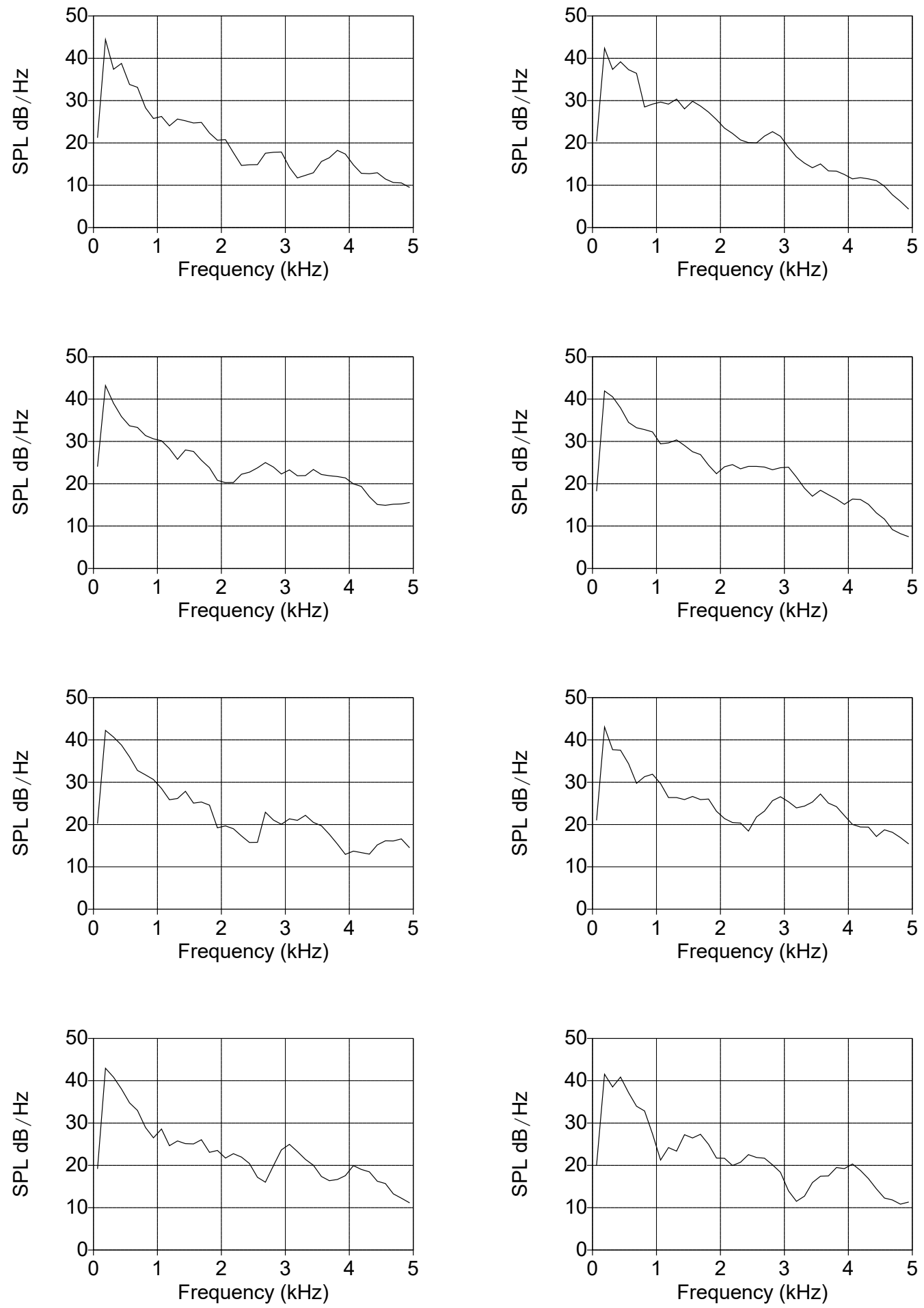

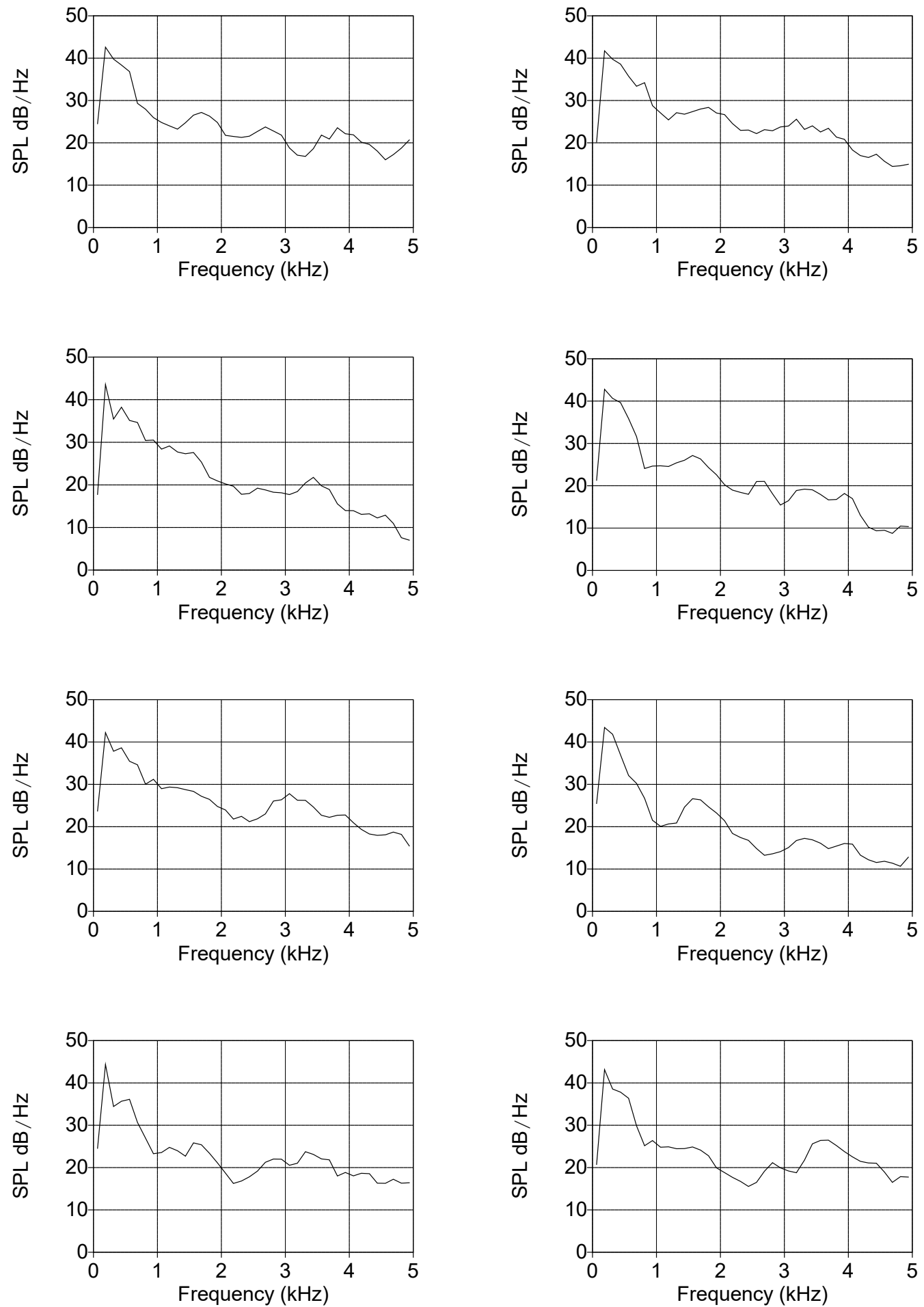

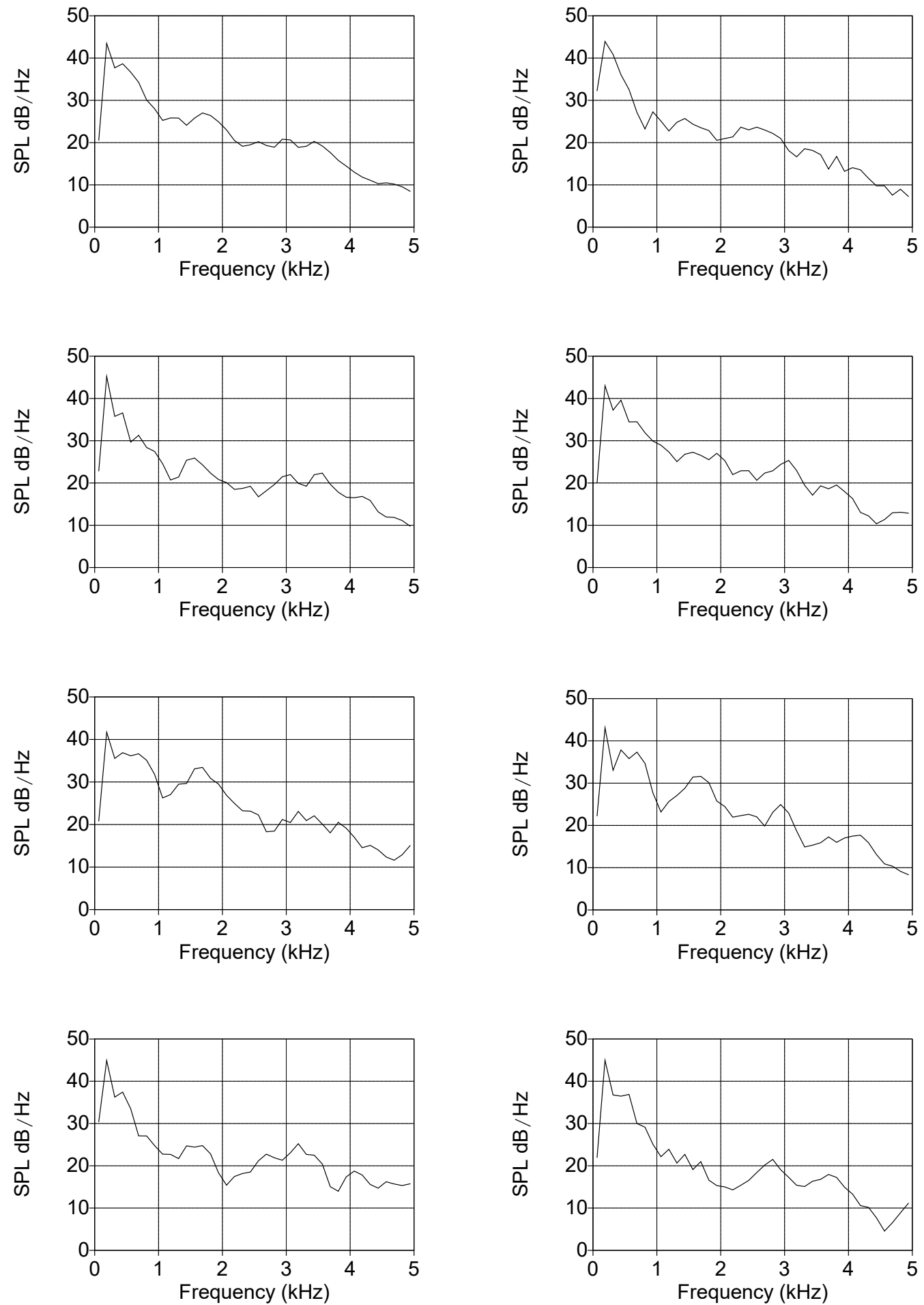

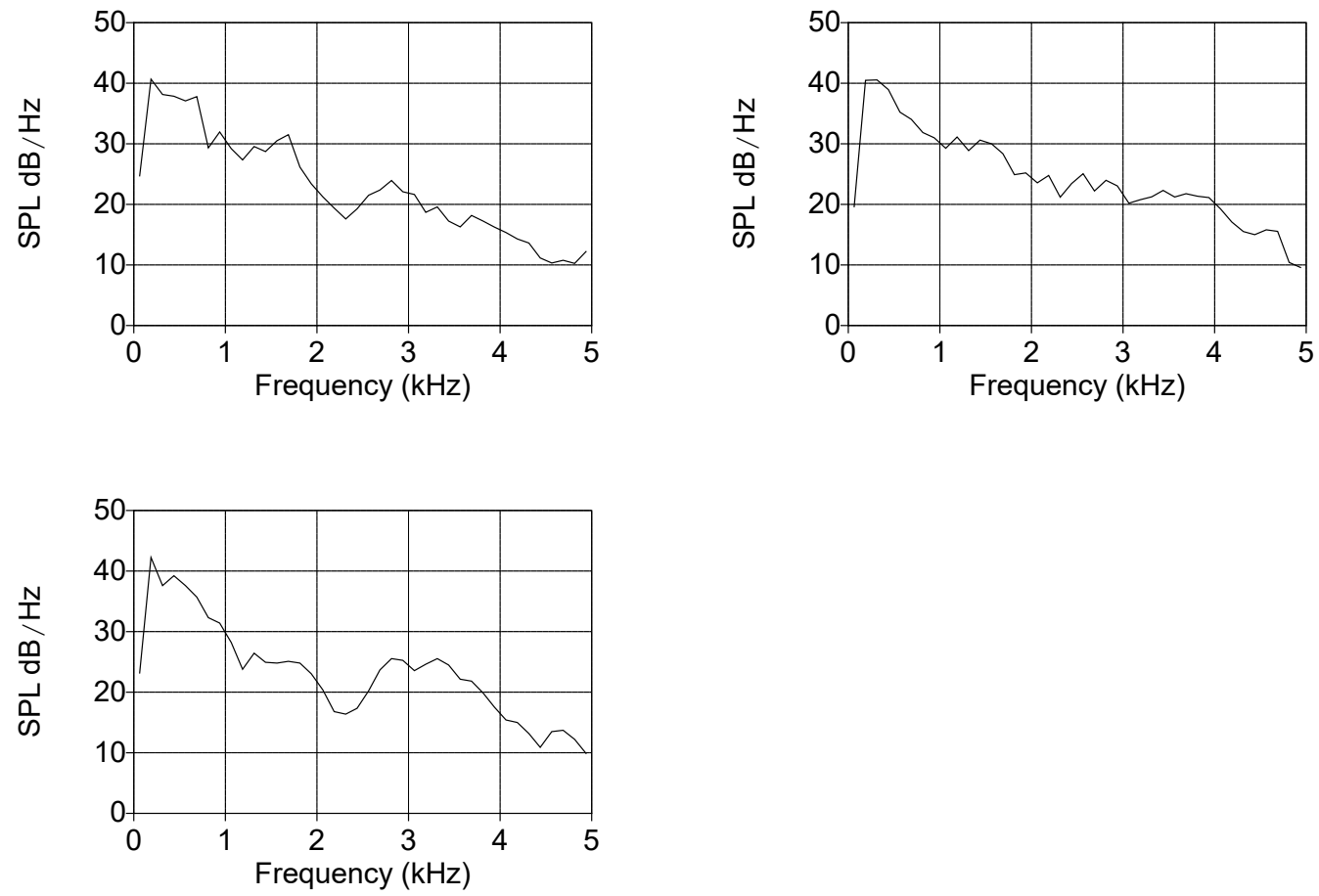

\section{PRILOG 4}

Pojedinačni dugotrajni prosječni spektri govora nastavnica s vokalnim zamorom, $N=23$
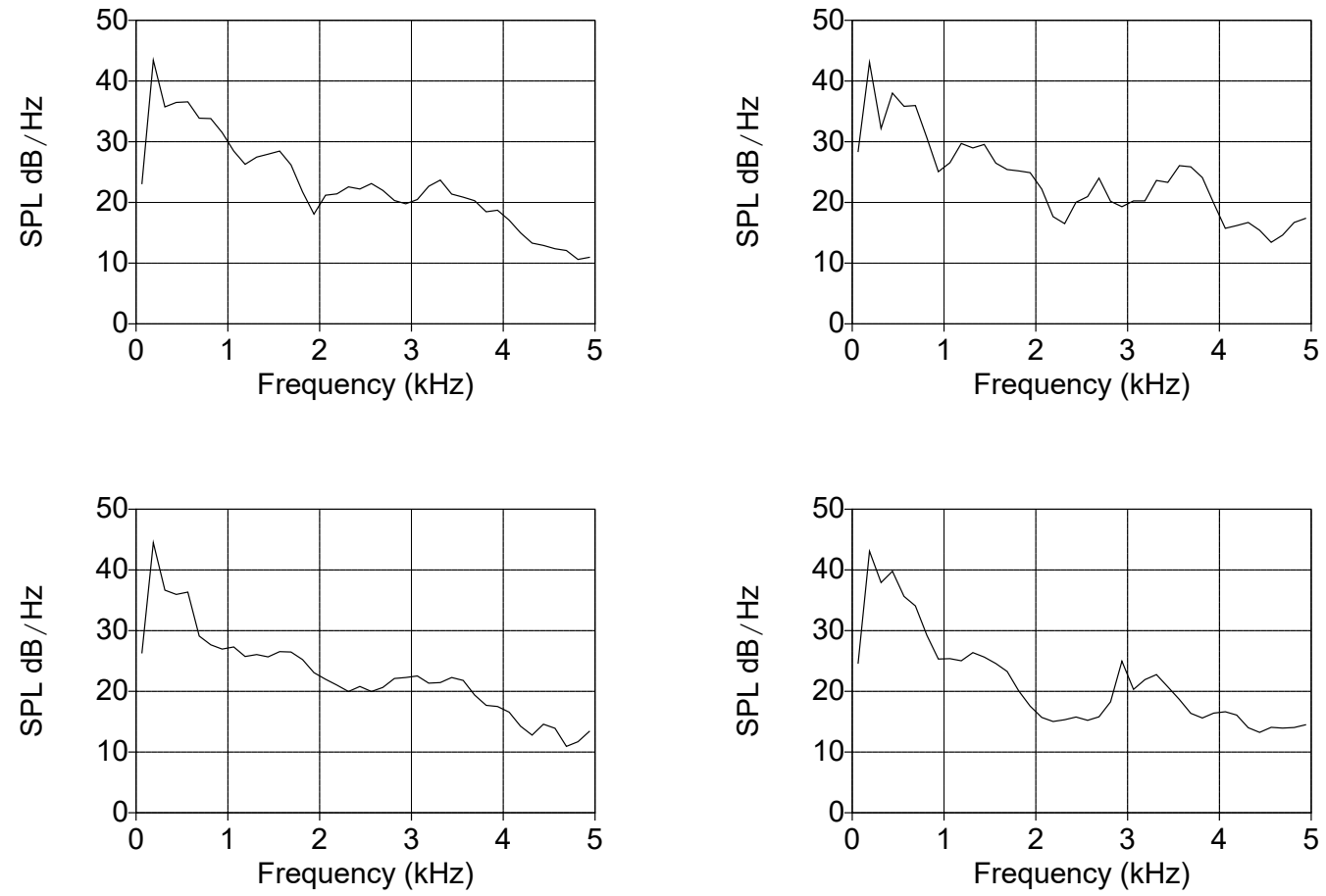

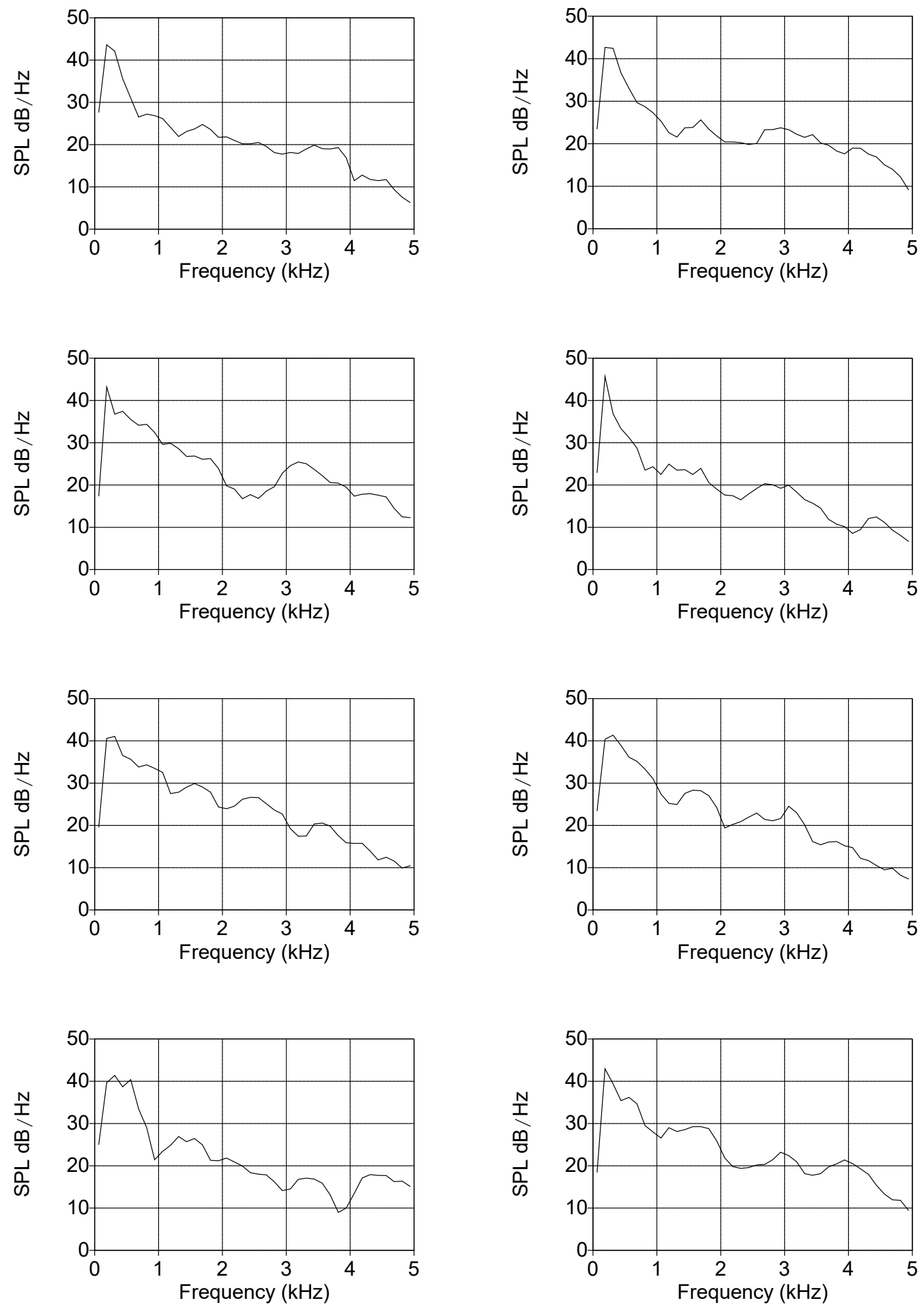

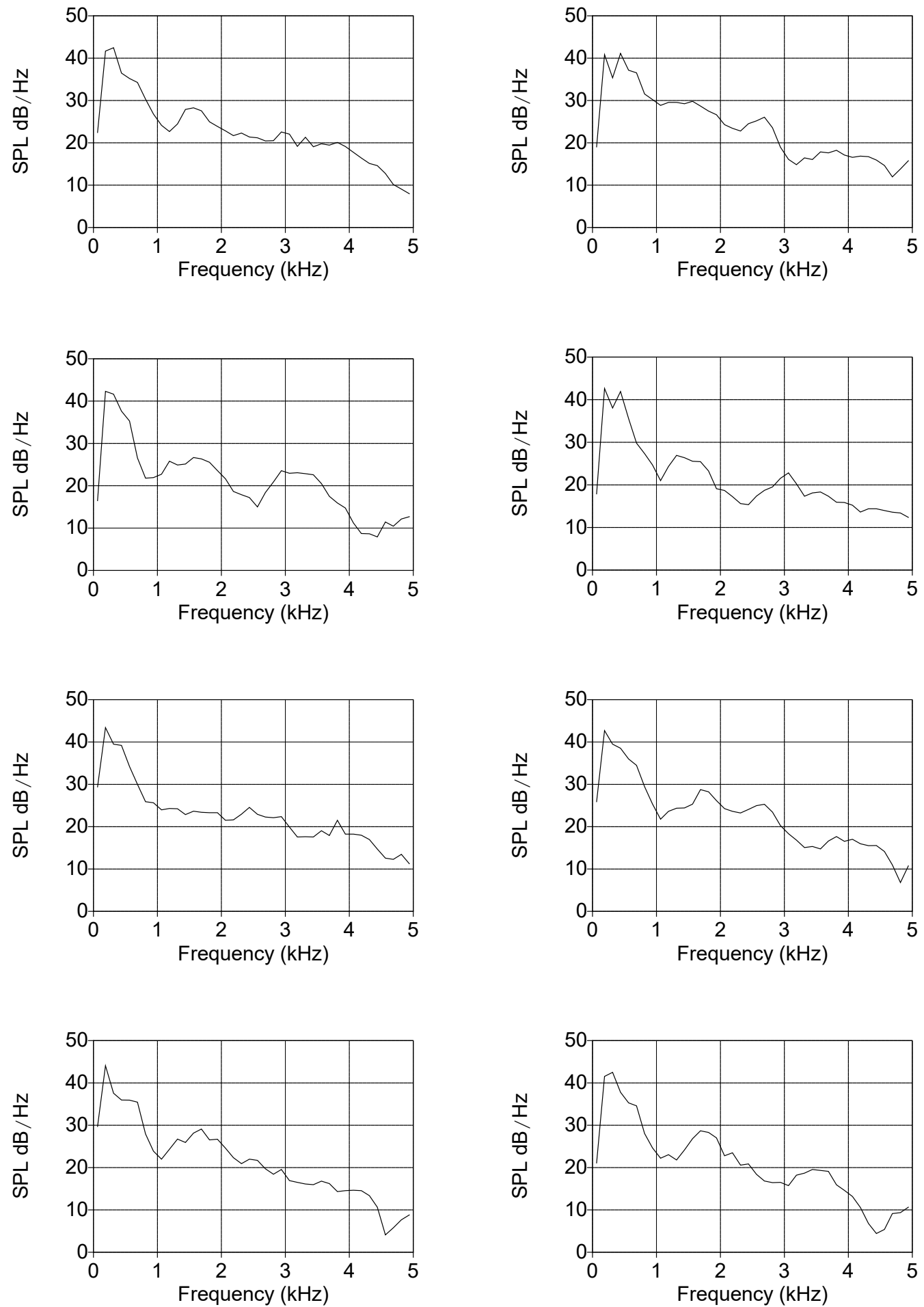

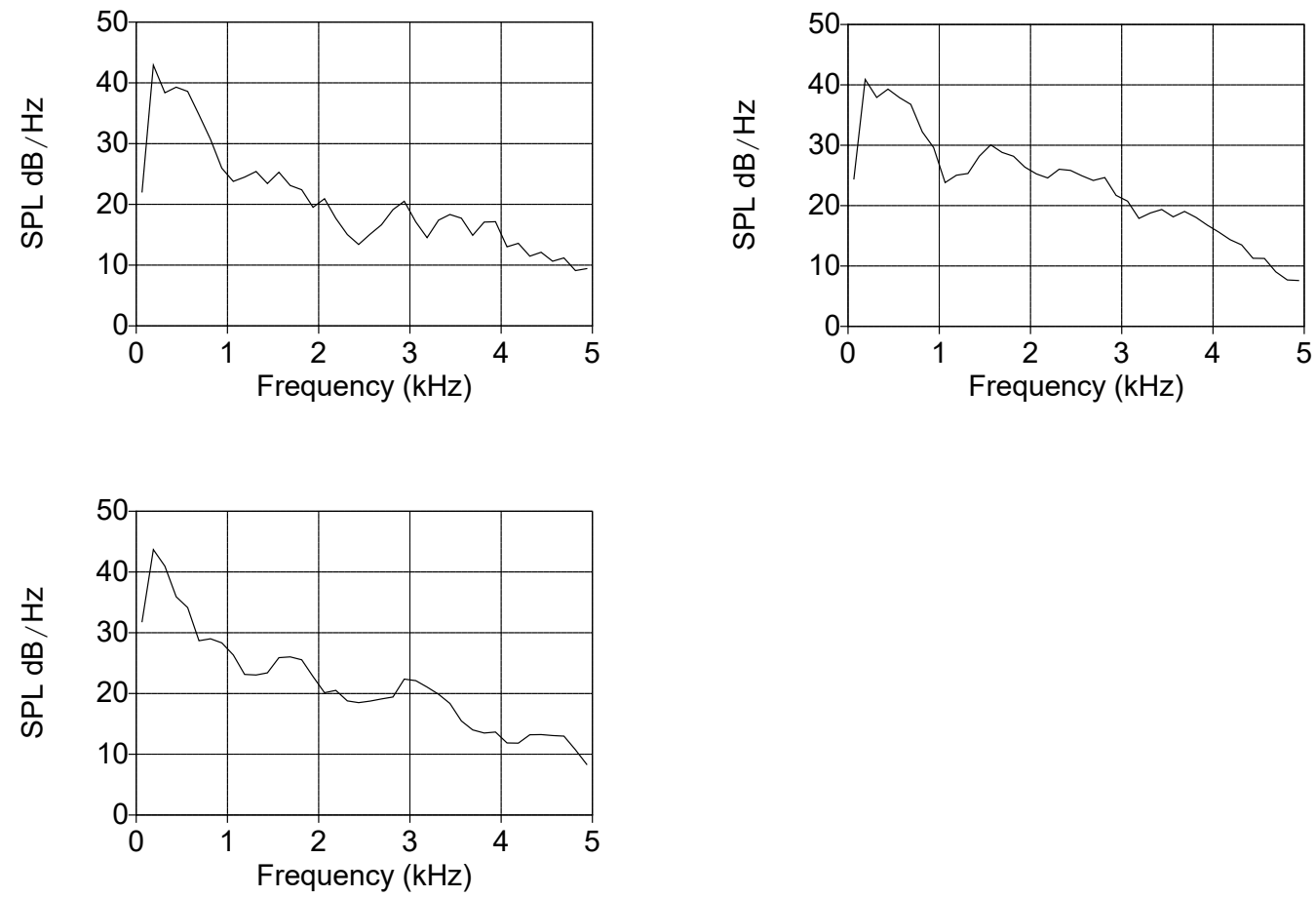